Fall 2013

\title{
The Dangers of Psychotropic Medication for Mentally Ill Children: Where Is the Child's Voice in Consenting to Medication? An Empirical Study
}

Donald H. Stone

University of Baltimore School of Law, dstone@ubalt.edu

Follow this and additional works at: http://scholarworks.law.ubalt.edu/all_fac

Part of the Civil Rights and Discrimination Commons, Disability Law Commons, and Policy Commons, Juvenile Law Commons, and the Medical Jurisprudence Commons

\section{Recommended Citation}

The Dangers of Psychotropic Medication for Mentally Ill Children: Where Is the Child's Voice in Consenting to Medication? An Empirical Study, 23 Temp. Pol. \& Civ. Rts. L. Rev. 121 (2013)

This Article is brought to you for free and open access by the Faculty Scholarship at ScholarWorks@University of Baltimore School of Law. It has been accepted for inclusion in All Faculty Scholarship by an authorized administrator of ScholarWorks@University of Baltimore School of Law. For more information, please contact snolan@ubalt.edu. 


\title{
THE DANGERS OF PSYCHOTROPIC MEDICATION FOR MENTALLY ILL CHILDREN: WHERE IS THE CHILD'S VOICE IN CONSENTING TO MEDICATION? AN EMPIRICAL STUDY
}

\author{
by DONALD H. STONE*
}

\section{INTRODUCTION}

When a child with a mental illness is being prescribed psychotropic medication, who decides whether the child should take the medication-the parent or the child? What if the child is sixteen years of age? What if the child is in foster care: Should the parent or social service agency decide? Prior to administering psychotropic medication, what specific information should be provided to the person authorized to consent on behalf of the child? Should children be permitted to refuse psychotropic medications? If so, at what age should a child be able to refuse such medication? What procedures should be put in place to forcibly medicate a child with psychotropic medication?

There are numerous reports indicating that children in foster care are overmedicated as compared to children not in foster care. ${ }^{1}$ What are the reasons for this occurrence? Are there abuses within the foster care system? Should the state mental health agency monitor psychotropic medications for children, require oversight or a second opinion, or monitor abuse? What authority should a state agency have to stop prescribing psychotropic medication to children?

This article will explore the overmedication of children with mental illness, with a specific emphasis on foster care children. Part I will examine the use of psychotropic medication on children, from the viewpoint of psychiatrists, pediatricians, parents, and children. ${ }^{2}$ Part II will explore the reasons why foster children receive psychotropic medications at a higher rate than children under their parents' care. ${ }^{3}$ Part III will provide an explanation of the consent procedures for children, and a critical inquiry into the manner psychiatrists and psychiatric

\footnotetext{
* Donald H. Stone, Professor of Law at the University of Baltimore School of Law, B.A., Rutgers University, J.D., Temple University School of Law. I gratefully acknowledge my research assistant, Abby C. Boyd, a 2014 graduate of the University of Baltimore School of Law. In addition, special thanks to Dr. Erik Roskes, Clinical Director, Forensic Services, Springfield Hospital Center, for his insight, advice, and assistance in the discussions we had on the mentally ill child.

1. See Julie M. Zito et al., Psychotropic Medication Patterns Among Youth in Foster Care, 121 PEDIATRICS e157, el62 (2008) (expressing doubts about "whether the dispensing of $\geq 3$ different psychotropic medication classes concomitantly to children in foster care represents a treatment advantage").

2. See infra Part I (examining the viewpoints of psychiatrists, pediatricians, parents, and children).

3. See infra Part II (considering why foster children receive psychotropic medications at a higher rate than other children).
} 
hospitals undertake to address a minor's refusal to take psychotropic medication. ${ }^{4}$

Additionally, Part I will analyze various states' responses to addressing both the overmedicating of children as well as consent and refusal issues that ultimately result from the medication of children. ${ }^{5}$ It will offer recommendations for a model consent form to be utilized by psychiatrists and in-patient psychiatric hospitals. ${ }^{6}$ It will present the rights of children to refuse psychotropic medication as recommended, and the procedure for overriding such refusal. ${ }^{7}$

Finally, Part III will analyze a survey of psychiatrists and pediatricians on the use of psychotropic medications to understand the existing consent procedures governing a minor's refusal to take psychotropic medications. ${ }^{8}$ The survey's design allows for a better understanding of the reasons behind the overmedication of foster children. The analysis will highlight the best practices and offer recommendations that provide for a state reporting and monitoring system.

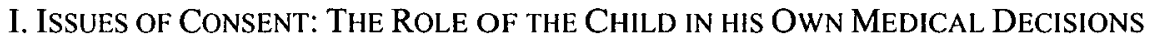

\section{A. The Parent, the State as Parents Patraie, or the Child: When is a Minor Medicated, and Who Decides?}

Should children of a certain age be authorized to consent or refuse psychotropic medication? The legal system, for the most part, has set the age of consent as the age of majority (age eighteen). ${ }^{9}$ However, the significant and intrusive nature of psychotropic medication justifies changing this determinative age. ${ }^{10}$ The mature minor should be permitted a voice in the decision-making process of this meaningful and life-altering event. ${ }^{11}$

In another area where decisions are made about a child's medical care, a minor's choice to have an abortion, the U.S. Supreme Court has evaluated the rights of parents to be notified prior to the procedure being performed on a minor. ${ }^{12}$ In Hodgson v. Minnesota, ${ }^{13}$ a statute requiring a parent's consent for a minor's

4. See infra Part III (explaining consent procedures for children and inquiring into how psychiatrists and psychiatric hospitals address a minor's refusal to take psychotropic medication).

5. See infra Part I.C (analyzing how states address the overmedicating of children and ability to consent).

6. See infra notes 189-215 and accompanying text (recommending a model consent form).

7. See infra Part I.B-D (recommending the rights of children to refuse psychotropic medication and the procedure for overriding such refusal).

8. See infra Part III (analyzing a survey of psychiatrists and pediatricians on the use of psychotropic medications).

9. Kimberly M. Mutcherson, Whose Body is It Anyway? An Updated Model of Healthcare Decision-Making Rights for Adolescents, 14 CORNELL J.L. \& PUB. POL'Y 251, 259 (2005).

10. See Jennifer Albright, Free Your Mind: The Right of Minors in New York to Choose Whether or Not to Be Treated with Psychotropic Drugs, 16 ALB. L.J. SCl. \& TECH. 169, 177 (2006) ("A minor who can exercise adult judgment should be able to give consent to psychotropic medication.").

11. See id. at 178 ("Given the known adverse side effects and still unknown permanent effects, minors should be allowed to participate in the decision whether or not to take psychotropic medications.").

12. Hodgson v. Minnesota, 497 U.S. 417, 449 (1990).

13. 497 U.S. 417 (1990). 
abortion was evaluated through the traditional common law perspective of requiring parental consent for any medical procedure performed on minors. ${ }^{14}$ The Court held that in certain cases, a minor need not receive consent from a parent to obtain the medical procedure. ${ }^{15}$ The autonomy of the minor's right to consent or refuse psychotropic medication should be viewed as akin to other significant medical decisions which recognize their authority. ${ }^{16}$

Similarly, in Planned Parenthood of Central Missouri v. Danforth, ${ }^{17}$ the Supreme Court acknowledged that the ability to make good decisions does not come into being as soon as one attains the state-defined age of majority. 18 The Court has likened this to other areas of a child's decision making, such as undergoing an operation, marrying, or entering military service, and the Court noted that parental consent is often needed to counter the immaturity, inexperience, and lack of judgment that impairs the ability of a minor to exercise her rights wisely. ${ }^{19}$ However, the Court has also acknowledged that for certain minors, a judicial bypass as an alternative to parental consent, at least for obtaining an abortion, should be available where a minor may demonstrate that she is sufficiently mature, despite her age, to make the decision herself. ${ }^{20}$

The Court in Hodgson recognized that the "mature minor" is capable of making the important and significant decision to obtain an abortion. ${ }^{21}$ Courts should similarly respect these mature minors enough to allow them to make significant decisions in other areas, such as medication refusal. ${ }^{22}$ Medicating a minor with psychotropic drugs, as compared with decisions regarding marriage and enlisting in the military, is different due to the intrusive nature of forcing mind-altering drugs onto one's own person. ${ }^{23} \mathrm{~A}$ minor's right to his own bodily integrity should be respected..$^{24}$ A minor's desire to avoid being forcibly medicated should be

14. Id. at $422-23$.

15. Id.

16. See id. (upholding a statute authorizing a minor to give effective consent without parental involvement for treatment of pregnancy and complications associated with venereal disease, alcohol, and drug abuse).

17. 428 U.S. 52 (1976).

18. See id. at 74 ("Constitutional rights do not mature and come into being magically only when one attains the state-defined age majority.").

19. Bellotti v. Baird, 443 U.S. 622, 634-39 (1979).

20. Hodgson, 487 U.S. at 455 (permitting the minor to demonstrate the abortion is in her best interest).

21. Id. at 430 .

22. See Jennifer L. Rosato, The Ultimate Test of Autonomy: Should Minors Have A Right to Make Decisions Regarding Life-Sustaining Treatment?, 49 RUTGERS L. REV. 1, 5 (1996) ("In most circumstances, mature minors should be able to make life-sustaining treatment decisions themselves. Age should not impose an artificial barrier to a minor's right to self-determination.").

23. Myers v. Alaska Psychiatric Inst., 138 P.3d 238, 242 (Alaska 2006) ("[T]he truly intrusive nature of psychotropic drugs may be best understood by appreciating that they are literally intended to alter the mind. Recognizing that purpose, many states have equated the intrusiveness of psychotropic medication with the intrusiveness of electroconvulsive therapy and psychosurgery.").

24. See Dennis E. Cichon, The Right to "Just Say No": A History and Analysis of the Right to Refuse Antipsychotic Drugs, 53 LA. L. REV. 283, 377 (1992) ("[A]ntipsychotic drugs are much more intrusive than temporary physical restraints, encroaching upon bodily integrity and personal security to a far greater degree."). 
acknowledged. ${ }^{25}$ A minor should be permitted to stand pat and prohibit the intrusive nature of psychotropic medication over the objection of her doctor. ${ }^{26}$

There are often competing interests involved in the health and welfare of children. ${ }^{27}$ Parents are used to addressing and providing for the well-being of their minor children. ${ }^{28}$ Because of this, the state intervenes only if the parents' decisionmaking and actions undermine the child's best interests. ${ }^{29}$ Unfortunately, the rights and responsibilities of a minor child in consenting to important matters affecting his own health and safety is so often an afterthought. ${ }^{30}$ The autonomy of a mature minor, independent of the parents, should be acknowledged. ${ }^{31}$

In the landmark U.S. Supreme Court case Wisconsin v. Yoder, ${ }^{32}$ the rights of parents conflicted with the responsibility of the state over Wisconsin's compulsory education law. ${ }^{33}$ The Court addressed the power of the state as parens patriae to require secondary education for children against the wishes of their Amish parents. ${ }^{34}$ Finding no demonstration of harm to the physical or mental health of the child, or threat to public safety or welfare, the Court held that the rights of the parents trumped the important state interest in creating an educated citizenry. ${ }^{35}$ Interestingly, the dissent in Yoder highlights an important, albeit unresolved, issue as to what happens if the child's wishes conflict with the parent's wishes regarding school attendance. ${ }^{36}$ Similar conflicts occur if the state, parent, and minor child do not agree over whether psychotropic medication should be prescribed. ${ }^{37}$

In Sombrotto $v$. Christiana $W .{ }^{38}$ a New York state court examined the rights of parents to object to a hospital's petition to involuntarily administer psychotropic

25. See Susan D. Hawkins, Protecting the Rights and Interests of Competent Minors in Litigated Medical Treatment Disputes, 64 FORDHAM L. REV. 2075, 2077 (1996) ("[A] competent minor's right to make certain medical decisions for herself should receive protection ....").

26. See id. at 2077 ("If a minor has the right to choose to undergo such an invasive procedure as an abortion, then certainly she should have the right to refuse or accept other forms of medical treatment on her own behalf.").

27. See id. at 2080-90 (examining the respective interests of parents and the state in medical treatment cases in an effort to explain why, traditionally, a minor's parents and the state have been the only parties who have enjoyed standing in such cases).

28. See id. at 2075 ("Parents generally have the sole authority to decide whether their children will receive such treatment, and a physician may not treat a minor without the consent of the minor's parent or guardian.").

29. See id. at 2086 ("Even though the child's interests are at stake in medical treatment cases, courts tend to consider only the parents' and the state's interests in the outcome.").

30. See id. ("The interests of the child are deemed secondary, if considered at all.").

31. See Hawkins, supra note 25, at 2132 ("Courts in litigated medical treatment disputes must recognize that competent minors have rights and interests, apart from those of their parents and the state, that require protection.").

32. 406 U.S. 205 (1972).

33. Id. at 207-09.

34. Id. at 229-34.

35. Id. at $230,234$.

36. Id. at $244-46$.

37. See Albright, supra note 10, at $189-90$ ("Some parents may consent, or refuse consent, to the use of psychotropic drugs for their children based on religious or moral beliefs.").

38. 852 N.Y.S.2d 57 (N.Y. App. Div. 2008). 
medication to their fourteen-year-old child. ${ }^{39}$ The court recognized, on the basis of state law, that either the consent of a parent or guardian or the authorization of a court is required for the non-emergency administration of psychotropic medication to a minor residing in a hospital. ${ }^{40}$ The court held that great deference must be accorded to a parent's choice as to the mode of medical treatment to be undertaken and the physician selected to administer the law. ${ }^{41}$

The Sombrotto court acknowledged that even when the parent's decision to decline necessary treatment is based on constitutional grounds, it must yield to the state as parens patriae if the parent's decision poses a threat to the health and welfare of the child. ${ }^{42}$ However, there was no evidence presented that the child was suffering from a life-threatening condition, no negative side effects were present, and no long-term life-enhancing benefit to prescribing the medication over the parent's objection. ${ }^{43}$ Accordingly, the parent's decision trumped the state's desire. ${ }^{44}$

While parents generally have a constitutional right to make medical decisions for their children, this changes if the parents are unfit. ${ }^{45}$ When children are neglected and placed in the care of a social services agency, the rights of parents to provide consent for the administration of psychotropic medication are called into question. ${ }^{46}$ The District of Columbia Court of Appeals addressed this issue in In re G.K. ${ }^{47}$ a case of first impression. ${ }^{48}$ In determining whether the Child and Family Services Agency ("CFSA") had authorization to provide consent for the administration of psychotropic medication, the court focused on the significance of psychotropic medication. The court did not look to whether the administration was

39. Id. at 58 ("[A]fter conducting a hearing to which the parents were not parties.").

40. Id. at 60-61 (relying on an Article 10 of the Family Court Act); see also Matter of Bennett v. Jeffreys, 40 N.Y.2d 543, 546 (1976) (acknowledging that every parent has a fundamental right to raise his child).

41. Sombrotto, 852 N.Y.S.2d at 62 .

42. Id. at 63; see also In re W.H., 25 A.3d. 330, 337 (Pa. Super. Ct. 2011) (setting forth the procedures to obtain a court-ordered consent for medical treatment for children under legal custody of the county department of public welfare).

43. Sombrotto, 852 N.Y.S.2d at 63; see also Rivers v. Katz, 67 N.Y.2d 485, 497-98 (1986) (setting forth the standard of proof as clear and convincing evidence that psychotropic medication was warranted).

44. Sombrotto, 852 N.Y.S.2d at 63-64.

45. See Maska v. Maska, 742 N.W.2d 492, 497 (Neb. 2007) (affirming a district court's order that because each parent was fit, "each parent was allowed to make medical decisions on an emergency basis for the benefit of the children when the children were in his or her physical custody"); J.W.J., Jr. v. P.K.R., 999 So. 2d 943, 951-52 (Ala. Civ. App. 2008) (holding that a fit parent can make medical decisions regarding his child); State ex rel. Juvenile Dep't of Multnomah Cnty. v. Smith, 133 P.3d 924, 930 (Or. Ct. App. 2006) (holding that mother had not become sufficiently educated or involved in either minor's life or her treatment to be qualified to make decisions regarding minor's medical care).

46. See JoAnne Solchany, A.B.A. Ctr. ON ChILd. And the LaW, Psychotropic Medication AND CHILDREN IN FOSTER CARE: TIPS FOR ADVOCATES AND JUDGES 18 (Claire Sandt Chiamulera ed., 2011) (stating that for children in foster care, it is the state or children's administration, the foster parent caring for the child, or the courts that may have the authority to consent to medication for children in foster care).

47. 993 A.2d 558 (D.C. 2010 ).

48. Id. at 559 (analyzing the situation of a child placed in the care of the District of Columbia Child and Family Services Agency by the court in order to decide whether to authorize in-patient psychotropic medication for the child). 
within the course of ordinary medical care. ${ }^{49}$ Instead, it held that psychotropic medication was a much more invasive medical treatment that would require additional consent. ${ }^{50}$ Whether a neglected child is prescribed psychotropic medication is "presumptively within the ambit of residual parental rights-subject to the Family Court's responsibility as parens patriae: to intervene, if necessary, to protect a child's best interest." 51 The court prohibited the CFSA from consenting to administer the psychotropic medication, and held that a more formal and thorough process conducted by the trial court should have determined whether medication was in the child's best interest. ${ }^{52}$ The D.C. court set forth the directive that a family court "cannot exercise its discretion as parens patriae to intervene and overrule a parent's prerogative unless it finds by clear and convincing evidence that doing so would be in the best interests of the child." ${ }^{33}$ As no such hearing was held, the decision to override the parent's objection to the psychotropic medication was reversed and the parent's wishes were honored. ${ }^{54}$

Providing consent to medicate their children with psychotropic medications has great significance to parents. ${ }^{55}$ The ability to consent to psychotropic medications should be viewed as far more invasive and compelling than consenting to general medical care. ${ }^{56}$ When children are removed from their parents for abuse or neglect and placed in the care of a social services agency, the social services agency commonly seek a generalized consent for basic medical treatment. ${ }^{57}$ However, authorizing consent for potent psychotropic medication for children is quite different. ${ }^{58}$

49. Id. at 566 (explaining that because psychotropic medication is not ordinary medical care, decisions regarding a neglected child's psychotropic medication were presumptively within the scope of residual parental rights).

50. Id. at 566-67.

51. Id. at 566 (holding that the CFSA lacked statutory authorization to consent).

52. Id. at 569 ("While the Family Court has the authority to overrule a natural parent's prerogative regarding a neglected child's psychotropic medication, this discretion must be exercised, where appropriate, after a careful consideration of all the relevant factors. And from the limited record before us here, we cannot say whether the Family Court properly exercised its discretion in this case.").

53. In re G.K., 993 A.2d at 570 .

54. Id.

55. See SOLCHANY, supra note 46 , at 18 (noting that biological parents may disagree with foster parents as to whether or not a child should be medicated, and that having the decision made by someone who knows the child's specific needs is critical).

56. See id. at 4 (explaining that while psychotropic medications can be beneficial, misdiagnoses or incorrect medications can "derail" or "sabotage" children's mental healing).

57. See lourdes M. Rosado, JuVEnile LAw CTR., CONSENT to TREATMENT and Confidentiality Provisions AfFecting MinOrS in PEnNSylvania 11-12 (2006) (explaining the regulations surrounding the ability of various child welfare services in Pennsylvania to consent to medical treatment for minors in their custody); see also SOLCHANY, supra note 46, at 18 (stating that in some states, it is "the state or children's administration, the foster parent caring for the child, the court, or state designated panels or overseers" that have the authority to consent to medication for children in foster care. In other settings such as group homes, residential treatment centers, or inpatient psychiatric institutions, physicians or staff may have consent to treat, which may include consent to administer medications).

58. See Michael W. Naylor et al., Psychotropic Medication Management for Youth in State Care: Consent, Oversight, and Policy Considerations, 86 CHILD WELFARE 175, 179 (2007) ("The use of psychotropic medications by children in state care presents unique challenges, particularly regarding 
In In Re Martin F., ${ }^{59}$ an antipsychotic drug had been prescribed to a threeyear-old child over the objection of her mother. ${ }^{60}$ The Family Court in New York explained that the consent to medicate required additional consent to be obtained, separate from the more generalized consent usually obtained from parents when a child enters protective custody ${ }^{61}$ This acknowledgment that medicating children is different and far more significant than consent for general medical care is to be applauded.

The parent who has his child removed due to allegations of abuse or neglect often feels overwhelmed. ${ }^{62}$ In Martin $F$, the Department of Human Services ("DHS") that removed the three-year-old child routinely consulted parents, who were given an opportunity to consent to treatment. ${ }^{63}$ But if the parents did not consent, their objections were simply overridden. ${ }^{64}$ DHS's erroneous practice is more evidence of the vulnerability of parents interacting with the foster care system..$^{65}$ In its decision, the court relied on the notion that prescribing psychotropic drugs is different than prescribing other medications, necessitating a higher level of judicial scrutiny. ${ }^{66}$ The court held that the decision to administer Depakote was unwarranted because it lacked an administrative review procedure or court review. ${ }^{67}$

Furthermore, the court distinguished "uncontroversial, immediate, and

issues of consent for and the oversight of psychotropic medications.").

59. 820 N.Y.S.2d 759 (N.Y. Fam. Ct. 2006).

60. Id. at 760-61. (explaining that after a child was placed in foster care based on her mother's neglect, the Department of Human Services sought consent to administer Depakote sprinkles over the objections of the child's mother).

61. Id. at 762-63 ("Thus, merely on the face of the state statute and its supporting regulations, it might appear that the Commissioner of Human Services can simply determine what prescription medicines shall be given to each and every child in foster care, without consulting with parents, but after consulting with appropriate professionals. Such a simple process, however, does not recognize, or take into consideration, the constitutional rights (1) of parents to make typical parental/family decisions for their children and (2) of children to be protected from unwarranted state intrusion into their mental and physical well-being.").

62. See, e.g., Kris Betts \& Matt Olsen, Father of Foster Child Who Died Speaks to KVUE (Aug. 1, 2013, 9:51 PM), http://www.kvue.com/news/Father-of-murdered-foster-child-speaks-to-KVUE218037541 html (describing a father's concerns about the treatment of his daughter in the foster system and his reaction to discovering how his child died in foster care); see also MARION CNTY. CHILD. SERV., Frequently Asked Questions, http://www.marionkids.com/faqs.html (last visited Oct. 27, 2013) ("Parents who abuse or neglect their child are often under stress, pressure or in the midst of a crisis. Some parents were abused themselves as children. Often families are overwhelmed and cannot cope with personal, financial or marital problems.").

63. 820 N.Y.S.2d at 766 .

64. Id. at 763 .

65. Sandra Stukes Chipungu et al., Meeting the Challenges of Contemporary Foster Care, 14 CHILD., FAM., AND FOSTER CARE 75, 78 (2004) ("Families who come to the attention of the child welfare system are vulnerable families with complex needs.").

66. In re Martin F., 820 N.Y.S.2d at 773 (noting that the due process and fundamental liberty interests of both parent and child were ignored in this case); see also Santosky v. Kramer, 455 U.S. 745, 747-48 (1982) (explaining the due process rights of parents who have neglected their children).

67. In re Martin F., 820 N.Y.S.2d at 768 (noting that because of the lack of an administrative review process, the decision to administer the medication was made without deciding the merits of the mother's objections). 
necessary care to foster children" from "potentially damaging mental health drugs . . . ."68 The former is non-intrusive while the latter may not work and can be objectionable to reasonable parents. ${ }^{69}$ A parent's wishes may be usurped when there is sufficient medical evidence to invoke the state's parens patriae authority, and if the child's welfare will be served by the disputed treatment. ${ }^{70}$ The court recognized the compelling state interest in utilizing its police power only where the patient presents a danger to himself or others, engages in dangerous conduct while institutionalized, or if the patient lacks the capacity to consent to take the drug."

The Family Court held that the DHS violated the due process rights of parents because the DHS gave them no real rights--only the opportunity to consent. ${ }^{72}$ The court announced that the proper standard to be applied under the states' parens patriae power to override a child's mental health medication determination over parental objection was as follows:

[I]f the parent of a child in foster care opposes the administration of mental health medicine it cannot lawfully be prescribed unless the court determines, after a hearing de novo with counsel, whether the proposed treatment by medication is narrowly tailored to give the substantive effect to the child patient's liberty interest, "taking into consideration all relevant circumstances, including the child patient's best interest, the benefits to be gained from the treatment, the adverse side effects associated with the treatment, and any less intrusive alternative treatments." 73

Because the mother's refusal to consent should have been honored, the court found that the case did not support the application of the parens patriae power to override the mother's reasonable objection to Depakote Sprinkles being given to her daughter. ${ }^{74}$

Subsequent to a child being placed in foster care, a social service agency generally seeks consent from the parent prior to administering psychotropic medication to the child ${ }^{75}$ The details of this process are spelled out in the case of $I n$

68. Id.

69. Id.; see also Rivers, 67 N.Y.2d at $497-99$ (explaining that forcible medication to adults in psychiatric hospitals as not always allowed).

70. In re Martin F., 820 N.Y.S.2d at 770; see also Matter of Cabrera, 552 A.2d 1114, 1118 (Pa. Super. Ct. 1989) ("Accordingly, in cases where harm to the physical or mental health of the child is demonstrated, these legitimate state interests may override the parents' qualified right to control the upbringing of their children.").

71. In re Martin F., 820 N.Y.S.2d at 771; see also Rivers, 67 N.Y.2d at 498-99 (addressing an adult's due process rights to oppose medication, thus requiring a judicial determination).

72. In re Martin F., 820 N.Y.S.2d at 771-72; but see In re A.S., 205141 Cal. Rptr. 3d 255, 264 (2012) (holding that a two-day requirement for a parent to file opposition to medication was reasonable).

73. In re Martin F., 820 N.Y.S.2d at 772 (emphasis omitted) (quoting Rivers, 67 N.Y.2d at 497-98).

74. Id. at 773 .

75. See Naylor, supra note 58, at 182 (stating that the most common method for welfare agencies to obtain consent to provide psychotropic medications to youth in state custody is for legal guardians or parents to give consent). 
re Lyle $A .^{76}$ The court was critical of the DHS's method of obtaining the mother's consent because the social services caseworker, rather than the prescribing psychiatrist, spoke to the mother seeking her consent. ${ }^{77}$ In addition, the court faulted the caseworker for failing to provide the mother with information on reasonably foreseeable risks and benefits, and alternative medications if the first drug failed. ${ }^{78}$ The court held that an objecting parent should be permitted to consult with an attorney just as an adult mentally ill patient held in a mental health facility has a right to counsel.$^{79}$ Furthermore, the court was critical of the DHS's failure to properly handle parental requests for changes in treatment, including requests to withdraw parental consent. ${ }^{80}$ The court emphasized the fundamental point that a parent has the right to make medication determinations, even when their child is in foster care. ${ }^{81}$ The burden is placed on the DHS to demonstrate that the parent was provided with the necessary information, given an opportunity to meet with the prescribing physician, and an attorney to review the consent form with sufficient time for the process to unfold in each case. ${ }^{82}$

When the state and parent agree that a child should be medicated, but the child voices disagreement, what, if any, legal obligation should the court possess in intervening to address the conflict? The traditional view that a parent possesses the legal authority to consent to medical treatment for the minor child should be questioned in light of the serious and dangerous consequences of prescribing psychotropic medication to children. ${ }^{83}$ The court should put in place a legal avenue to address the grievance of a mentally ill child disputing the treatment plan agreed upon by parent and psychiatrist. ${ }^{84}$ The grievance process usually administered by an independent judicial officer for mentally ill adults who dispute the medication treatment plan should be extended to both minors and their parents. ${ }^{85}$

76. 830 N.Y.S.2d 486 (N.Y. Fam. Ct. 2006) (addressing the process of obtaining parental consent and responding to a parental request to withdraw consent).

77. Id. at 490 .

78. Id. at 490-92 (discussing the failure of the caseworker to meet the requirements that would permit the parent to make an informed decision).

79. Id. at 494 .

80. Id. at 487,494 .

81. Id. at 495; see also In re Martin F., 820 N.Y.S.2d at 769 ("The fundamental liberty interest of natural parents in the care, custody and management of their child does not evaporate simply because they have not been model parents or have lost temporary custody of their child to the State." (quoting Santosky v. Kramer, 455 U.S. 745, 753 (1982)) (internal quotation marks omitted)).

82. In re Lyle A., 830 N.Y.S.2d, at 496.

83. See Rivers, 67 N.Y.2d at $497-98$ (stating that the parent of a child in foster care can legally deny consent to administer psychotropic drugs to a child unless a court rules otherwise); see also SOLCHANY, supra note 46, at 4 ("Medications can help children and teens in foster care, but they can also further impair them, derail them, and sabotage them.").

84. See Hawkins, supra note 25 , at 2077 ("[T] he Court has extended to minors the fundamental rights of privacy and bodily integrity in the contraception and abortion contexts. In keeping with this trend of affording children greater protection under the Constitution, a competent minor's right to make certain medical decisions for herself should receive protection in most instances as well. If a minor has the right to choose to undergo such an invasive procedure as an abortion, then certainly she should have the right to refuse or accept other forms of medical treatment on her own behalf." (footnotes omitted)).

85. Id. at 2093 ("Given the recent judicial trend towards affording children greater protection under the Constitution, a minor's right to make medical decisions for herself should receive full protection, 


\section{B. Let Their Voices Ring: The Mature Child Who Opposes Psychotropic Medication}

There are occasions when a minor may refuse to consent to the administering of psychotropic medication for the treatment of a mental illness. ${ }^{86}$ Focusing on situations when a minor is hospitalized in a psychiatric facility, a treating psychiatrist may be confronted with a situation where a minor refuses to comply with the medication regimen. ${ }^{87}$ Should the psychiatrist seek parental approval, court authorization, or honor a minor's refusal to consent? This fundamental question turns on the issue of the rights of mentally ill children to control their mental health treatment plan and the authority of others to override such a medication refusal. ${ }^{88}$

The decision to admit a child to a psychiatric hospital is often solely in the hands of the parent. ${ }^{89}$ In Parham V. J.R.,90 the United States Supreme Court acknowledged that parents have a traditional interest in and responsibility for the upbringing of their child, and therefore they retain a substantial role in the decision on commitment, absent a finding of neglect or abuse. ${ }^{91}$ The Supreme Court

and a minor should enjoy standing in contested medical treatment cases to protect her rights of informed consent, bodily integrity and self-determination, and privacy." (citation omitted)).

86. See, e.g., In re E.G., 549 N.E.2d 322, 325 (Ill. 1989) (holding that a minor who the court has determined to possess a requisite degree of maturity has limited rights to refuse life-sustaining medical treatment); see also Rhonda Gay Hartman, Coming of Age: Devising Legislation for Adolescent Medical Decision Making, 28 AM. J. L. \& MED. 409, 420 (2002) ("Affording adolescents legal autonomy for mental health treatment has occupied recent state legislative activity, resulting in varying requirements and policy goals that are aimed at encouraging adolescent access to treatment. States that recognize a minor's legal consent for mental health treatment usually place the onus for treatment determination on the minor, as illustrated by Pennsylvania's provision that a minor who is fourteen years or older may consent to examination and treatment if the minor 'believes that he is in need of treatment and substantially understands the nature of voluntary treatment." (footnote omitted)).

87. Some states allow children to refuse treatment, unless the treatment is court ordered. See, e.g., State of Wisconsin, Dep'T of Health SERv., Rights of Minors in Inpatient Community Mental Health Facilities, http:/www.dhs.wisconsin.gov/publications/p2/p20470a.pdf (last visited Oct. 27, 2013) (describing the right of minors fourteen years of age or older, who are admitted to inpatient mental health facilities in the state of Wisconsin, to refuse treatment unless treatment is court ordered).

88. See Heather boonstra et al., The Guttmacher Report on Public Policy, Minors and THE RIGHT TO CONSENT TO HEALTH CARE 4 (2000) ("On the one hand, it seems eminently reasonable that parents should have the right and responsibility to make health care decisions for their minor child. On the other hand, it may be more important for a young person to have access to confidential medical services than it is to require that parents be informed of their child's condition . . . Recognizing this reality, many states explicitly authorize a minor to make decisions about their own medical care, but balancing the rights of parents and the rights of minors remains a topic of debate."); $c f$. Michael Leonard Goff Jr., Protecting Our Mentally IIl: A Critique of the Role of Indiana State Courts in Protecting Involuntarily Committed Mental Patients' Right to Refuse Medication, 76 IND. L.J. 983, 984 (2001) ("Indiana courts should recognize that a patient's fundamental rights are not contingent upon their commission status and should be afforded full protection by applying strict judicial scrutiny to unwanted treatment decisions.").

89. See, e.g., ILLINOIS ChILDREN'S MENTAL HEALTH PARTNERSHIP, RESIDENTIAL, TREATMENT FOR

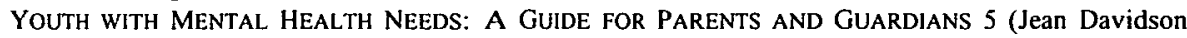
Meister ed.) ("The decision to place a child in a residential facility is one of the most difficult and most important choices that you can make for your child.").

90. 442 U.S. 584 (1979).

91. Id. at 604 . 
recognized, however, that a child does have a substantial liberty interest in not being confined unnecessarily for medical treatment, ${ }^{92}$ in part because such commitment sometimes produces adverse social consequences for the child. ${ }^{93}$ The Court also recognized that the state is not without constitutional control over parental discretion in dealing with children when their mental health is jeopardized. ${ }^{94}$

In our legal system, parents are the primary decision-makers for their children, even over their child's objections, when it comes to medical procedures..$^{95}$ Children are not viewed as capable of making sound judgments for certain care or treatment. ${ }^{96}$ However, there is a significant difference between a minor medical procedure, like a tonsillectomy or appendectomy and a more significant procedure, like obtaining an abortion or refusing psychotropic medication in a psychiatric hospital. ${ }^{97}$ Recognizing this difference, the Court in Parham held that "the risk of error inherent in a parental decision to have a child institutionalized for mental health care is sufficiently great [to require an inquiry] by a 'neutral fact-finder' to [ensure] the statutory requirements for admission are satisfied." $" 98$

Next consider the situation where a child is no longer living in the care of a parent but instead is placed in the custody of a social service agency. In the absence of a parent's decision-making power over this child, the court system has a responsibility to consider the voice of a mature child to speak on the issue of receiving or refusing psychotropic medication. ${ }^{99}$ This child should be front and center in the decision-making process. ${ }^{100}$ Of course, when all parties are in

92. Id. at 600 .

93. Id.; see also Addington v. Texas, 441 U.S. 418, 425-26 (1979) ("Moreover, it is indisputable that involuntary commitment to a mental hospital after a finding of probable dangerousness to self or others can engender adverse social consequences to the individual."); cf. Application of Gault, 387 U.S. 1, 23-24 (1967) (discussing the social stigma of labeling a juvenile as a delinquent).

94. Parham, 442 U.S. at 603 (additionally noting that a child not receiving proper medical treatment and behaving abnormally in public may be ostracized or harmed, and that the child thus has a protectable interest in not being labeled erroneously).

95. See id. at 603 ("Most children ... are not able to make sound judgments concerning ... their need for medical care or treatment. Parents can and must make those judgments.").

96. Id.

97. See, e.g., Danforth, 428 U.S. at 75 (declaring a state statute that enabled parents to veto a minor child's decision to have an abortion unconstitutional)

98. Parham, 442 U.S. at 606.

99. See, e.g., TENNESSEE DeP'T OF CHILDREN's SERviCES, CliEnT's Rights HaNDBook 8 (2012), available at http://tennessee.gov/youth/pdfs/clientsrights.pdf (stating that Tennessee allows mature fourteen-year-olds who are in the custody of the Department of Children's Services ("DCS") to refuse treatment if it is determined that the child is mature enough to make such a decision; the decision by a mature fourteen-year-old to refuse medical treatment or tests can only be overridden by judicial intervention, which can only be sought after DCS consults with the prescribing healthcare provider and it is determined that the treatment is in the best interests of the child and will protect the child from harm).

100. See, e.g., In re E.G., 549 N.E.2d at 327-28 (discussing the mature minor doctrine and stating that "[i]f the evidence is clear and convincing that the minor is mature enough to appreciate the consequences of her actions, and that the minor is mature enough to exercise the judgment of an adult, then the mature minor doctrine affords her the common law right to consent to or refuse medical treatment"). 
agreement as to the proper course of treatment, there is no compelling need for judicial review. However, when the parent, social service agency, or child dissent, objective third-party review is necessary. Children must be entitled to more protections than adults, ${ }^{101}$ necessitating third-party scrutiny and oversight, likely by a judicial or administrative review. ${ }^{102}$

Finally, a state's interest in administering psychotropic medication has been seen as legitimate and important in certain situations, even over the consent of the individual being medicated. ${ }^{103}$ Specifically, courts have ruled that an individual may be forcibly medicated if that person is a prison inmate with a serious mental illness. ${ }^{104}$ Even then, the treatment must be found to be in the inmate's medical interest, ${ }^{105}$ and the inmate must found to be dangerous to himself or others. ${ }^{106}$

Similarly, in Riggins v. Nevada ${ }^{107}$ the Supreme Court addressed the rights of inmates to object to the administering of anti-psychotic drugs. ${ }^{108}$ The Court in Riggins set further limits on the forced medication of prison inmates, specifically that the state must determine if there are less intrusive alternatives and determine that the medication was medically appropriate and necessary for the inmate's safety or the safety of others. ${ }^{109}$

The Supreme Court later addressed the use of psychotropic
medication forcibly administered solely in order to render a
defendant competent to stand trial. ${ }^{110}$ In Sell $v$. United States, ${ }^{11 !}$ the
Court permitted the government to involuntarily administer anti-
psychotic drugs to mentally ill defendants if the treatment is
medically appropriate, substantially unlikely to have side effects, and
if the state explores less intrusive alternatives-and, even then, only
to ensure that the defendant has a fair trial. ${ }^{12}$ This was a landmark
decision, for it marked the first time the Court held that a defendant
could be medicated, not due to dangerous behavior, but rather to
address the need to bring the defendant to trial. The Court found an

101. See Parham, 442 U.S. at 627 (noting that children are entitled to more protection than adults and are, on average, confined for longer periods than adults).

102. See, e.g., Washington v. Harper, 494 U.S. 210,233 (1990) (finding that administrative review by medical decision-makers is an appropriate safeguard against a violation of a patient's due process rights when they are medicated against their will).

103. See, e.g., id. at 236 (holding that the state interest in providing antipsychotic drugs outweighed the inmate's liberty interest in refusing medical care).

104. See, e.g., id. (holding that the forced administration of antipsychotic drugs to prisoners is permissible under the Constitution).

105. See, e.g., id. at 225 (stating that prison administrators have a duty to provide for prisoners' medical interests).

106. See, e.g., id. at 236 (holding forced administration of antipsychotic drugs to inmates is constitutional because it reduces the dangers that inmates present to themselves and others).

107. 504 U.S. 127 (1992).

108. Id. at 133 .

109. Id. at 135 .

110. See Sell v. United States, 539 U.S. 166, 169 (2003) (holding it constitutional to administer antipsychotic drugs to a mentally ill criminal defendant to render him competent to stand trial).

111. Id.

112. Id. at $180-81$. 
important governmental interest in bringing to trial a competent individual accused of a serious crime. ${ }^{113}$

However, extending this right of the state from forcibly medicating a prison inmate to forcibly medicating a child who has committed no crime and merely diagnosed with a mental illness is quite a leap. ${ }^{114}$ The governmental interests in a fair trial, preserving evidence, and avoiding memory loss of key witnesses are not central to the decision to forcibly medicate a child who has committed no crime. ${ }^{115}$

In situations involving the refusal to consent to psychotropic medication, even an adult's decision is not absolute. ${ }^{116}$ In Maryland, for example, an involuntarily committed, dangerous, mentally ill person may be forced to receive psychotropic medication through an oversight clinical review panel and ultimately an administrative hearing. ${ }^{117}$ Maryland law provides for a minor at age sixteen to have the same capacity as an adult to consent to treatment of a mental health or emotional disorder. ${ }^{118}$ However, such capacity does not exist when a parent or guardian of the minor has given consent. ${ }^{119}$

Courts have laid out the criteria for the forcible medication of the mentally ill, confined patient. ${ }^{120}$ In Maryland, the state's highest court articulated that standard as requiring a finding that the patient was a danger to himself or others while confined at the mental health facility. ${ }^{121}$ The Kelly court restricted forcible medication to situations where a mentally ill patient confined to a state institution poses a danger to himself or others in the context of his confinement within the state institution rather than, if released, to the general community. ${ }^{122}$

113. Id. at 179 (finding that the government has a substantial interest in timely prosecution to avoid lost evidence and fading memories due to a delay in bringing the defendant to trial).

114. See, e.g., Superintendent of Belchertown State Sch. v. Saikewicz, 370 N.E.2d 417, 425 (Mass. 1979) (stating that the right for a state to force a minor to receive medical treatment serves four governmental interests: "(1) the preservation of life; (2) the protection of the interests of innocent third parties; (3) the prevention of suicide; and (4) maintaining the ethical integrity of the medical profession").

115. Id.

116. See, e.g., MD. CODE ANN., HEALTH-GEN. $§ 10-708$ (b) (West 2013) (stating that a doctor may administer medication in an emergent situation where the patient presents a danger to the life and safety of himself or others as well as in a non-emergent situation where the patient is involuntarily committed and the medication is approved by a panel).

117. Id.

118. MD. Code ANN., HEALTH-GEN. § 20-104 (West 2013).

119. Id.

120. See generally Jurasek v. Utah State Hosp., 158 F.3d 506, 511 (10th Cir. 1998) ("Accordingly, the Due Process Clause allows a state hospital to forcibly medicate a mentally ill patient who has been found incompetent to make medical decisions if the patient is dangerous to himself or others and the treatment is in the patient's medical interests."); Steinkruger v. Miller, 612 N.W.2d 591, 600 (S.D. 2000) (holding that South Dakota's scheme for forcibly medicating mentally ill patients comports with the Due Process Clause of the Fourteenth Amendment); Katz, 495 N.E.2d at 498 (holding that forcibly administering medication is constitutional after the court balances the individual's liberty interest "against the State's asserted compelling need on the facts of each case").

121. Dep't of Health \& Mental Hygiene v. Kelly, 918 A.2d 470, 492 (Md. 2007).

122. Id. at 492; see also Youngberg v. Romeo, 457 U.S. 307, 324 (1982) (holding a mentally ill person confined to a state institution possesses a liberty interest protected by the due process clause of the Fourteenth Amendment to safe conditions, freedom from unreasonable bodily restraints, and minimally adequate or reasonable training). 
This standard, of proving that the patient must be at substantial risk of continued hospitalization due to remaining mentally ill, in the context of the institutionalization, represents a higher threshold to require forcible medication than previous cases permitted. ${ }^{123}$ The Kelly court placed a reasonable limitation on the hospital's authority to forcibly medicate a patient who objects, properly reigning in such power. ${ }^{124}$ What follows from the Maryland forced medication cases should be the recognition that we must respect and honor the wishes of the mentally ill patient and her freedom from intrusive psychotropic medication without the necessary judicial oversight. ${ }^{125}$

\section{Who Consents: Ethical Issues When Prescribing Psychotropic Medication to Children}

What should we as a society do when the decision to medicate mentally ill children arises? When the need to medicate arises, social service agencies and courts seek to obtain informed consent from all the parents. ${ }^{126}$ Physicians often turn to parents, guardians, or social service agencies to provide consent for minors. ${ }^{127} \mathrm{As}$ a last resort, some states provide an independent physician to review or judicial authorization to provide the necessary consent. ${ }^{128}$ However, where is the recognition that mature, competent children should be consulted on the matter of psychotropic medication? ${ }^{129}$ At age sixteen, a minor may very well be capable of authorizing consent or refusing to consent to such medication administration..$^{130}$ There are two distinct and separate decisions to be made with respect to

123. See Kelly, 918 A.2d at 489 (quoting the Supreme Court's standard in Harper regarding the permissibility of forcible medication of psychotic drugs on a mentally ill inmate); see also Williams $\mathrm{v}$. Wilzack, 573 A.2d 809, 821 (Md. 1990) (recognizing an inmate has a significant constitutional liberty interest to be free from arbitrary administration of anti-psychotic drugs).

124. Kelly, 918 A.2d at 492 (holding that Maryland Department of Health and Human Hygiene was not authorized to forcibly medicate the patient, who was not involuntarily confined to medical facility after he was found not competent to stand trial, without a finding that the patient was a danger to himself or others while confined in the medical facility).

125. Id.

126. See, e.g., S.D. CODIFIED LAWS $§ 27$ A-15-46 (2013) (requiring oral and written informed consent from a parent or guardian when a minor under sixteen is prescribed psychotropic medication); $\S 27 \mathrm{~A}-15$ 47 (requiring oral and written informed consent from a parent or guardian and from a minor who is age sixteen or older when the minor is prescribed psychotropic medication).

127. See Hodgson, 497 U.S. at 483 ("The common law historically has given recognition to the right of parents, not merely to be notified of their children's actions, but to speak and act on their behalf.").

128. See Harper, 494 U.S. at 233 (holding administrative review by medical decision-makers is sufficient to satisfy the due process rights of a patient who was forcibly medicated).

129. See Jay C. Costello, Why Have Hearings for Kids if You Are Not Going to Listen?: A Therapeutic Jurisprudence Approach to Mental Disability Proceedings for Minors, 71 U. CIN. L. REv. 19,27 (2002) (analogizing a competent minor's right to an abortion with a competent minor's right to refuse or consent to psychotropic medication).

130. See Supplemental Security Income: Determining Disability for a Child Under Age 18, 58 Fed. Reg. 47532-01 (Sept. 9, 1993) (to be codified at 20 C.F.R. § 416) (acknowledging "the functional abilities, skills, and behaviors that are age-appropriate for 16-to-18-year-olds are those that are also ageappropriate for 18-year-olds"); Laurence Steinberg, A Social Neuroscience Perspective on Adolescent Risk-Taking, 28 DEVELOPMENTAL REV. J. 78, 80 (2008) (stating "[t]he logical reasoning and basic information-processing abilities of 16-year-olds are comparable to those of adults"). 
psychotropic medication for children. ${ }^{131}$ First, should doctors prescribe psychotropic medication when both the parent and child agree on accepting the medication? ${ }^{132}$ Next, what determines the course of action when either the parent or minor rejects the medication being prescribed? ${ }^{133}$ When the parent rejects, but the child consents, should physicians administer the medication or seek judicial approval? For the physician's protection, judicial approval is the appropriate course of action. ${ }^{134}$ What, however, should physicians do when the parent consents and the juvenile refuses? Add to this question that the minor is sixteen years of age and viewed as confident to consent. ${ }^{135}$ Should the physician ignore the wishes of the child and singly honor the parent's wishes when they conflict with the desires of the child? Physicians should again seek judicial approval. ${ }^{136}$ At such a proceeding, the wishes of the child should be considered in evaluating the issue of consent. ${ }^{137}$ There ought to be prescriptions that at age sixteen, the child's wishes should override the parents' wishes. ${ }^{138}$ Only if a court determines that the minor is not capable of providing informed consent should the parent's wishes be permitted to substitute for that of the minor child, at age sixteen and above. ${ }^{139}$

There is a considerable variation in state laws that provide for the age of consent for mental health treatment. ${ }^{140}$ On one extreme, in California, the threshold age where a minor may consent to mental health treatment is twelve years old. The child's ability to authorize does not include consent to psychotropic drugs, at least not without the consent of the minor's parent. ${ }^{141}$ In Florida, a minor at age thirteen

131. See generally Stephen A. Talmadge, Who Should Determine What is Best for Children in State Custody Who Object to Psychotropic Medication?, 15 ANNALS HEALTH L. 183, 187 (2006) ("Psychotropic medications can be administered either voluntarily or involuntarily.").

132. See, e.g., S.D. CODIFIED LAWS $\$ 27$ A-15-47 (2013) (allowing doctors to prescribe psychotropic medications to minors who are age sixteen or older if both the minor and parent provide informed consent).

133. See Susan O. Scheutzow, I HEALTh L. PraC. Guide $\S 11: 15$ (West 2013) (stating judicial intervention may be necessary when a parent and minor disagree about treatment).

134. Id.

135. See Andrew Newman, Adolescent Consent to Routine Medical and Surgical Treatment: A Proposal to Simplify the Law of Teenage Medical Decision Making, 22 J. LEGAL MED. 501, 531 (2001) ("In the absence of any scientific studies showing that a 16-year-old has less judgment than an 18-yearold (or older), the general consensus on a 16-year-old having sufficient competence should carry the day").

136. See Scheutzow, supra note 133 (stating judicial intervention may be necessary when a parent and minor disagree about treatment).

137. See People v. Medina, 705 P.2d 961, 973 (Colo. 1985) (stating a judge must ask the patient his views on the treatment at a judicial hearing).

138. See Newman, supra note 135, at 530-32 (arguing a bright line standard of giving sixteen year olds autonomy in medical standards would alleviate the burden on the court to determine the maturity of the minor).

139. See Grant H. Morris, "Let's Do the Time Warp Again": Assessing the Competence of Counsel in Mental Health Conservatorship Proceedings, 46 SAN DIEGO L. REV. 283, 294 (2009) (stating a guardian may give informed consent if an individual is determined to be incompetent).

140. See Hartman, supra note 86 , at $\mathbf{4 2 0}$ (stating limitations on whether adolescents can consent to mental health treatment varies considerably by state).

141. Cal. HeAlth \& SAFETy CODE $\$ 124260$ (West 2013) (stating that consent of the twelve year old is contingent on the attending professional assessment that the minor is mature enough to participate intelligently in the mental health treatment). 
may receive mental health diagnostic and evaluative services; however, psychotropic medication is exempt from such services. ${ }^{142}$ In Alabama, a minor who is fourteen years of age or older may provide consent to any legally authorized medical or mental health services, including psychotropic medications. ${ }^{143}$ Similarly, Oregon authorizes a minor at age fourteen to obtain outpatient diagnosis or treatment for a mental health disorder without parental knowledge or consent. ${ }^{144}$

The District of Columbia has also recognized the ability of older adolescents to consent to serious medical treatment. ${ }^{145}$ While minors under the age of sixteen may not consent to the administration of psychotropic medication in any event absent emergency, minors who are sixteen years and older are, able to consent to such treatments without parental approval in certain circumstances. ${ }^{146}$ Such a provision is a major step in acknowledging that a minor at age sixteen possesses the capacity to consent to receiving a psychotropic medication for the treatment of his or her own mental illness. ${ }^{147}$ State legislatures are encouraged to extend this protection to minors who have reached age sixteen by providing them with the exclusive authority to refuse or consent to the administration of psychotropic medication. ${ }^{148}$

A minor's authority to seek voluntary admission into a psychiatric in-patient facility for mental health services is occasionally stipulated in state legislation. For example, a minor can seek said admission in Colorado at age fifteen, ${ }^{149}$ and in Maryland, at age sixteen. ${ }^{150}$ These state legislatures, recognizing the maturity of older adolescents, grant them autonomy to make the serious decision to be voluntarily admitted into a psychiatric hospital. ${ }^{151}$ Other state legislatures should be encouraged to acknowledge the maturity of sixteen-year-olds and place similar decision-making authority in their hands. ${ }^{152}$

In light of the overwhelming evidence regarding problems involved with

142. Fla. STAT. ANN. $§ 394.4784$ (1)-(2) (West 2013); see also CONN. GEN. STAT. ANN. $§ 19 a-14 c$ (West 2013) (stating that a minor, at no minimum age, may receive mental health treatment, not including dispensing medication).

143. ALA. CODE $§ 22-8-4$ (West 2013); see also MICH. COMP. LAWs ANN. $§ 330.1707$ (West 2013) (permiting a minor at age fourteen to receive outpatient mental health treatment without the parent's consent with the exception of psychotropic drugs).

144. OR. REV. STAT. ANN. $§ 109.675$ (1) (2007); but see id. $\S 109.675(2)$ ("However, the person providing treatment shall have the parents of the minor involved before the end of treatment ...").

145. D.C. CODE $\$ 7-1231.14$ (c)(2)(a)-(c) (2001).

146. See id. (providing for situations where a minor would not have to rely upon parental consent for such treatment).

147. See id. (recognizing a sixteen-year-old's ability to consent in receiving psychotropic medication without parental consent in certain circumstances).

148. See id. (acknowledging sixteen as the appropriate age to give consent under particular circumstances); Newman, supra note 135, at 508 (regarding the recommended age of consent, absent parental agreement, for certain medical procedures: "[r]ather than engaging in subjective analyses of maturity factors, it would be simpler and more efficient to use a chronologic test, using age 16 as the cutoff').

149. COLO. ReV. STAT. ANN. $\S 27-65-103(2)$ (West 2010).

150. MD. CODE ANN., HEALTH-GEN. $\$ 10-609$ (a) (West 2009).

151. Id.; COLO. REV. STAT. ANN. § 27-65-103(2).

152. See Newman, supra note 135 , at 508 (stating that age sixteen is a suitable cutoff in determining the right to consent to medical treatment with or without parental consent). 
medicating minors with psychotropic medication-including, but not limited to concomitant use, prescribing these medications off-label and without FDA approval-we must ask ourselves: who is monitoring such actions on the part of the prescriber? There should be supervision prior to and during the treatment of children who are prescribed psychotropic medication. ${ }^{153}$ Psychiatric hospitals bear some responsibility to provide the risks and alternatives to psychotropic medication prior to administering such medication to their young patients..$^{154}$

Prior to prescribing psychotropic medications to minors, physicians should provide both the child and the parent the purpose of psychotropic medications, side effects, and alternative treatment options. ${ }^{155}$ For children in foster care, the explanation should also be given in person to a foster care caseworker or a designated medication consultant. ${ }^{156}$

In Maryland, for example, while a sixteen-year-old minor is permitted to seek voluntary admission to an in-patient psychiatric facility regardless of his or her parent or guardian's wishes, ${ }^{157}$ when said minor elects to refuse psychotropic medication, the hospital may, oddly enough, turn to a parent or guardian to authorize the psychotropic medication. ${ }^{158}$ Of course, treating psychiatrists have the option of using clinical review panels and administrative hearings to force a psychiatric patient to be medicated involuntarily. ${ }^{159}$ A treating psychiatrist, however, does not appear to be required to pursue this same forced medication route for a minor that is mandated for an adult. ${ }^{160}$ Treating psychiatrists should consider following the same approach that is followed for adults when treating minors. ${ }^{161}$ The treating psychiatrist who relies on the consent of the minor's parents

153. Glenn S. Hirsch, Guide to Psychiatric Medications for Children and Adolescents, ABOUT OUR KIDS.ORG, http://www.aboutourkids.org/articles/guide_psychiatric_medications_children_adolescents (last visited Oct. 24, 2013) ("Children should take these medications only under the careful supervision of their physicians.").

154. See Harvey Dondershire, Legal Aspects of Hospital Psychiatry, STANFORD.EDU, http://www.stanford.edu/group/psylawseminar/Inpatient.htm (last visited Oct. 24, 2013) (enumerating a list of questions to ask patients in order to procure adequate consent from a patient before administering psychotropic drugs to avoid hospital liability).

155. Psychiatric Medication For Children and Adolescents Part l-How Medications Are Used, AMERICAN ACADEMY OF CHILD \& ADOLESCENT PSYCHIATRY, (Nov. 2012), http://www.aacap.org/AACAP/Families_and_Youth/Facts_for_Families/Facts_for_Families_Pages/Psyc hiatric_Medication_For_Children_And_Adolescents_Part_I_How_Medications_Are_Used_21.aspx (last visited Oct. 27, 2013).

156. See SOlChANY, supra note 46 , at 4.

157. See MD. CODE ANN., HEALTH-GEN. \$ 10-609(a) ("Application for voluntary admission of an individual may be made under this section by the individual, if the individual is 16 years old or older.").

158. See MD. CODE ANN., HEALTH-GEN. $§ 20-104(a)(1)-(2)$ (West 2007) (stating that while sixteenyear-old persons have the capacity to consent to such treatment, they do not possess the capacity to refuse treatment for which a parent or guardian has given consent).

159. MD. CODE ANN., HEALTH-GEN. $§ 10-708$ (West 2009).

160. See id. (lacking indication of forced medication protocol for minors).

161. Ethics in Clerkships: Informed Consent, UNIVERSITY OF ILLINOIS AT CHICAGO COLLEGE OF MEDICINE, http://www.uic.edu/depts/mcam/ethics/ic.htm (last visited Oct. 27, 2013) (recognizing that the rights of parents regarding their children's medical treatment is not absolute and is sometimes subject to the doctrine of the "maturing adolescent" which can override parental consent in some situations). 
may be on thin ice when it comes to informed consent. ${ }^{162}$ The two conflicting regulations discussed above provide an example of the danger of not clarifying the rules, leaving them incongruous: one provides for a minor who is sixteen years of age to have the same capacity to consent to treatment for a mental disorder, while the other does not include the capacity to refuse treatment when a parent has consented. ${ }^{163}$ However, the only legitimate mechanism to forcibly medicate an involuntarily committed mentally ill individual is through forcible medication protocol. ${ }^{164}$ This creates an inherent problem when a parent consents to psychotropic medication for their minor child between sixteen and eighteen years of age but the minor refuses to consent to the medication. ${ }^{165}$ Psychiatrists should only resort to the forcibly medicating such patients through the forced medication avenue because there is no clear protocol for this particular situation. ${ }^{166}$ Anything less would allow a parent to override the wishes of his or her minor child (sixteen to eighteen years of age) under questionable legal authority. ${ }^{167}$ Because the statute provides that a sixteen-year-old has the ability to consent to treatment, this individual should also be able to have the capacity to refuse such medication without the threat of parental supersession. ${ }^{168}$

It is recommended that minors, upon reaching age sixteen, should be permitted to refuse to receive psychotropic medication. ${ }^{169}$ The next step for the treating psychiatrist who insists on forcibly medicating the minor patient should be to obtain judicially sanctioned permission. ${ }^{170}$ The legal process followed for adult

162. See id. (indicating that parental consent will not always qualify as "informed consent" in the case of "maturing adolescents").

163. MD. Code ANN., Health-Gen. \& 20-104(a)(1)-(2) (West 2007).

164. For an example of such a protocol, see, e.g., MD. CODE ANN., HEALTH-GEN. $\$ 10-708$ (West 2009) ("(b) Medication may not be administered to an individual who refuses the medication, except: (1) In an emergency, on the order of a physician where the individual presents a danger to the life or safety of the individual or others; or (2) In a nonemergency, when the individual is hospitalized involuntarily or committed for treatment by order of a court and the medication is approved by a panel under the provisions of this section.").

165. See MD. CODE ANN., HEALTH-GEN. $§ 20-104(a)(1)-(2)$ (stating that while sixteen year old persons have the capacity to consent to such treatment, they do not possess the capacity to refuse treatment for which a parent or guardian has given consent).

166. See Ethics in Clerkships: Informed Consent, supra note 161 (stating that parental rights are not necessarily absolute regarding a minor's consent to medical treatment due to the "maturing adolescent" theory).

167. See In re Roger S., 569 P.2d 1286, 1292 (1977) (supporting the conclusion that parental consent does not always equate to legality by holding that a fourteen year old minor was entitled to his own due process rights and his parents could not override them).

168. See Kathryn Hickey, Minors' Rights in Medical Decision Making, 9 JONA'S HEALTHCARE L, ETHICS, \& REG., 100, 102 (2007), available at https://nursing.ceconnection.com/nu/ovidfiles/00128488200707000-00013.pdf. (explaining that a minor "deemed able to understand short and long-term consequences is considered to be 'mature' and thus able to provide informed consent/refusal for medical treatment").

169. See Newman, supra note 135 , at 508 (stating that age sixteen is a suitable cutoff in determining the right to consent to medical treatment absent parental consent); see also In re E.G., 549 N.E.2d at 378 (holding that a minor who was competent enough to consent to life-sustaining treatment, was also competent enough to refuse that treatment).

170. See Ethics in Clerkships: Informed Consent, supra note 161 (supporting the conclusion that parental consent may not be the best avenue to force medication upon "mature adolescents" because it is 
patients who refuse psychotropic medication should be extended to those minor patients aged sixteen and above. ${ }^{171}$

One must consider what the treating physician should do if one or more of the key individuals - child, parent, or agency-disagree with the treatment plan being proposed. ${ }^{172}$ The American Medical Association's ("AMA") Code of Medical Ethics states, in part:

\begin{abstract}
The patient's right of self-decision can be effectively exercised only if the patient possesses enough information to enable an informed choice. The patient should make his or her own determination about treatment. The physician's obligation is to present the medical facts accurately to the patient or to the individual responsible for the patient's care and to make recommendations for management in accordance with good medical practice. ${ }^{173}$
\end{abstract}

The AMA clearly articulates the requirement, in accordance with good medical practice, of providing sufficient enough information to the patient so that he or she can make an informed choice. ${ }^{174}$ The AMA also acknowledges that the physician's obligation is to the patient himself, "or the individual responsible for the patient's care."175 The AMA should explicitly state its preferred approach for providing information to the minor patient who is mature enough to understand the risks and benefits of the treatment as well as to the parent of the patient. ${ }^{176} \mathrm{In}$ recommending psychotropic medication to children, the mature child and parent should be provided with information. ${ }^{177}$ The assessment of when a minor is mature enough to receive an explanation may vary, from eighteen to fourteen or sixteen, or the AMA could simply leave it in the hands of a treating physician to make a caseby-case assessment as to the maturity level of each individual minor patient individually. ${ }^{178}$

It is proposed that a more consistent approach should be established, with age

sometimes not dispositive of a mature adolescent's consent).

171. Id:; see Newman, supra note 135, at 508 (stating that age sixteen is a suitable cutoff in determining the right to consent to medical treatment absent parental consent).

172. See Hickey, supra note 168 , at 101 ("Matters become much more complicated when [competent minors and parents] disagree. Nursing administrators, who may be called upon to intervene, may need to seek legal counsel to sort out the variety of interests involved in these circumstances.").

173. Opinion 8.08 - Informed Consent, AM. MED. Ass'N, http://www.amaassn.org//ama/pub/physician-resources/medical-ethics/code-medical-ethics/opinion808.page (last updated Nov. 2006).

174. Id.

175. Id.

176. See Hickey, supra note 168 , at 103 ("The medical information of every individual is protected by federal and state constitutions, statutes, regulations, and previous court decisions. However, the ambiguous state of self-determination of adolescents presents challenges to confidentiality safeguards.").

177. Id.

178. See Opinion 8.08 - Informed Consent, supra note 173 ("Physicians should sensitively and respectfully disclose all relevant medical information to patients. The quantity and specificity of this information should be tailored to meet the preferences and needs of individual patients."). 
sixteen being the bright line cutoff for the age of consent. ${ }^{179}$ Physicians should still be able to make individual assessments as to how much information should be provided to patients; as the AMA puts it, the "quantity and specificity of medication information should be tailored to meet the preferences and needs of individual patients." 180 However, when it comes to the decision of receiving psychotropic medication, a consistent and standardized rule requiring sixteen and seventeen-year-old minors to consent and refuse medication should be imposed. ${ }^{181}$

When a sixteen year old refuses to consent to psychotropic medications, the physician should institute the same formal administrative or judicial override procedure that currently exists for adults who refuse psychotropic medication. ${ }^{182}$ This additional requirement would recognize the AMA mandate that a patient should make his own decision about treatment while also appreciating the significance of putting psychotropic medication into the bodies of our nation's children. ${ }^{183}$

The doctrine of informed consent has long been recognized as a guiding principle in medical treatment. ${ }^{184}$ The doctrine of informed consent imposes on a physician the duty to explain the procedure to the patient and to warn of any material risks or dangers inherent in the therapy prior to medical treatment. ${ }^{185}$ This enables the patient to make an intelligent and informed choice whether to undergo the proposed treatment. ${ }^{186}$ The importance of obtaining informed consent must be recognized for minors starting at the age of sixteen. ${ }^{187}$

\section{Recommendations for Obtaining Informed Consent}

Certain information should be provided to the child, parent or guardian prior to obtaining informed consent to medicate a child with psychotropic medication.

179. See Newman, supra note 135 , at $\mathbf{5 0 8}$ (stating that age sixteen is a suitable cutoff in determining the right to consent to medical treatment absent parental consent); see also Hickey, supra note 168, at 103 ("[T]he ambiguous state of self-determination of adolescents presents challenges to confidentiality safeguards.").

180. Opinion 8.08 - Informed Consent, supra note 173.

181. See Newman, supra note 135 , at 508 (supporting the conclusion that sixteen should be used as a bright line rule in determining a minor's capacity to consent without parental interference); see also In re E.G., 549 N.E.2d at 378 (holding a minor who was competent enough to consent to life-sustaining treatment was also competent enough to refuse that treatment).

182. See MD. CODE ANN., HEALTH-GEN. $§ 10-708$ (detailing the procedures available to override a patient's refusal of medication).

183. Opinion 8.08 - Informed Consent, supra note 173 ("The patient should make his or her own determination about treatment."); see Solchany, supra note 46, at 14 (indicating that the impact of psychotropic medication on children is more profound than it is on adults).

184. Sard v. Hardy, 379 A.2d 1014, 1019 (1977) (quoting Schloendorff v. Soc'y of New York Hosp., 105 N.E. 92, 93 (1914) (Cardozo, J.)) ("Every human being of adult years and sound mind has a right to determine what shall be done with his own body").

185. Id.

186. Id. at 1020 .

187. See Newman, supra note 135 , at 508 (stating that age sixteen is a suitable cutoff in determining the right to consent to medical treatment absent parental consent); see also Hickey, supra note 168, at 101 (indicating that discrepancies between the age of consent and "surrogate" decision making by parents leads to problems for physicians which must be remedied by the law). 
Where applicable, this information should also be provided to the social service agency that is responsible for the care and treatment of the child. ${ }^{188}$ At a minimum, the following information should be provided:

1. The list of medications prescribed;

2. The behavior or symptoms to which the medication is intended to modify; 189

3. The dosage, ${ }^{190}$ time of administration (both the starting and the maximum dose allowed), ${ }^{191}$ and frequency;

4. How possible side effects of the medication will be treated;192

5. The duration of the course of treatment for the administration of the medication; ${ }^{193}$

6. A description of the possible risks, side effects, interactions with other medications or foods, and complications of the medication; 194

7. Tests or procedures likely required as a result of the medication, before enduring the regimen; 195

8. Alternative treatments or medications;

9. The diagnosis or target symptoms for the medication; ${ }^{196}$

10. The benefits/intended outcomes of treatment; ${ }^{197}$

11. The likely results of not taking the recommended medication; ${ }^{198}$

12. The right to withdraw voluntary consent for medication at any time; 199

13. FDA status of the medication; ${ }^{200}$

14. Diagnosis (DSM-5); ${ }^{201}$

15. List of the child's non-psychotropic medications, including any nutritional

188. SOLCHANY, supra note 46 , at 4 .

189. N.J. ADMIN. CODE $\S 10: 127-7.5(\mathrm{e})(1)(\mathrm{i})(2009)$.

190. Id. at (b)(3)(i).

191. See Psychotropic Medication Treatment Plan Review, CF-FSP 5279, FLA. DEPT. OF CHILDREN \& FAMILIES (Sept. 2010), available at www.def.state.fl.us/initiatives/GMWorkgroup/docs/CFOP17598.pdf (describing a protocol for a case manager to request a prescribing practitioner to obtain a psychotropic medication treatment plan for the child).

192. N.J. ADMIN. CODE $§ 10: 127-7.5($ b)(3)(iv); OR. ADMIN. R. 413-070-0490 (2013).

193. MINN. R. 2960.0620 (2013).

194. NEV. ReV. Stat. ANN. $\$ 432 B .4687(2)(a)(6)$ (West 2011 ).

195. See MiNN. R. 2960.0620 (indicating that physicians need to inform patients of likely results and side effects of the medication).

196. ARIZ. DePT. OF Health Servi.,Psychotropic MEdiCation: PresCribing and Monitoring $\S 3.15$ (2010), available at http://www.azdhs.gov/bhs/provider/sec3_15.pdf. The form is also attached in Appendix A.

197. Id.

198. Id.

199. Id. (noting the right to withdraw consent subject to court order authorizing medication).

200. Id.

201. DSM-5 Development, AM. PSYCHIATRIC ASS'N, http://www.dsm5.org/about/Pages/faq.aspx (last visited Nov. 29, 2013) ("The Diagnostic and Statistical Manual of Mental Disorders (DSM) is the handbook used by health care professionals in the United States and much of the world as the authoritative guide to the diagnosis of mental disorders. . . DSM-5 is a manual for assessment and diagnosis of mental disorders and does not include information or guidelines for treatment of any disorder."). 


\section{supplements; ${ }^{202}$}

16. Explanation/reason for request to continue current medications, dosage adjustment, or new medication; ${ }^{203}$

17. Allergies and likely adverse reactions; ${ }^{204}$

18. Access to a website with monitoring protocols, maximum dosage guidelines, and approved medication list; ${ }^{205}$

19. Medication that was discontinued and the reasons for the discontinuation; ${ }^{206}$

20. Name and specialty of the licensed prescriber; ${ }^{207}$

21. Child's name, date of birth, and weight; ${ }^{208}$

22. Expiration date of the consent form, review date, duration of consent form shall not exceed 90 days; ${ }^{209}$

23. Concomitant medication use; 210

24. Requirement for second opinion in the following situations: medicating minors under the age of six, when the medication prescribed is "off-label" (when FDA protocol is not followed), ${ }^{211}$ when three or more psychotropic medications are prescribed at the same time, ${ }^{212}$ the first time a child is prescribed psychotropic medication, ${ }^{213}$ when a parent/guardian of a minor aged sixteen or older disagrees with the decision of the child; ${ }^{214}$

25. Notice of rights of child, parent or guardian, social service agency and treating psychiatrist if there is an objection to the use of the prescribed medication or prescribed dosage. ${ }^{215}$

The steps taken upon a sixteen-year-old minor's refusal to consent should be clearly spelled out in the consent form, and the prohibition on administering the

202. Psychotropic Medication Consent Request Form, CONN. DEP'T OF CHILDREN \& FAMILIES, http://www.ct.gov/dcf/cwp/view.asp?a=451 8\&q=386456 (last visited Oct. 27, 2013).

203. Id.

204. Id.

205. See, e.g., Psychotropic Medication Information, ConN. DeP'T OF ChILdREN \& Families, http://www.ct.gov/dcf/cwp/view.asp?a=4518\&q=386456 (last visited Oct. 27, 2013) (providing an example of such a website).

206. 89 ILL. ADMIN. CODE $\S 325.30(i)$ (12) (2012).

207. $\$ 325.30(i)(7)$.

208. $\S 325.30(\mathrm{i})(1)$.

209. ARIZ. DEPT. OF HEALTH SERVS., supra note 196.

210. See, e.g., Zito et al., supra note 1, at el 57 (concluding that concomitant psychotropic medication treatment is frequent for youth in foster care and lacks substantive evidence as to its effectiveness and safety).

211. See Solchany, supra note 46 , at 17 ('Using medications 'off label' is legal and has proved to benefit many individuals; however concerns have been raised about risks of widespread off-label use and the understanding of off-label use by prescribers and patients").

212. See 89 ILL. ADMIN. CODE $§ 325$ APP. A (2013) (adding that a child six years of age or younger being concomitantly prescribed three or more psychotropic medications "will trigger a closer review of a patient's care and possible denial of psychotropic medication requests").

213. See SOlchanY, supra note 46 , at 28 ("Successful medication management includes regular follow-ups. Especially when first started, medications often need to be adjusted for proper dosage or better timing.").

214. ARIZ. DEPT. OF HEALTh SERVS., supra note 196.

215. Id. 
prescribed medication over the objection of the minor, parent, or guardian without court order should be clearly delineated. ${ }^{216}$ The burden of proceeding with administering the medication on parent or guardian refusal should be with the party or agency seeking to medicate the minor. ${ }^{217}$ Prior to court authorization, no psychotropic medication should be administered unless an emergency exists. ${ }^{218}$

Extending legal protection to a child at age sixteen and above is an important step in restoring authority to mature minors. ${ }^{219}$ Such vulnerable children should be given a seat at the decision-making table. ${ }^{220}$ Foster children, who are often betrayed by their parents and forgotten by the foster care system, require the same protections but also additional oversight and monitoring to ensure their safety. ${ }^{221}$

\section{AN Indictment of the Mental HeAlth System For ChILdREN: OVERMEDICATION AND PARTICULAR CONCERNS FOR FOSTER CHILDREN}

\section{A. Warning Sign}

Children who are victims of abuse, neglect, or abandonment and placed in the foster care system present unique challenges to the psychiatric community. Many of these children have experienced traumatic events such as sexual abuse, physical and emotional abuse, and parental abandonment. ${ }^{222}$ As a result, these children often experience significant emotional harm and cross paths with mental health professionals. ${ }^{223}$ These damaged children are often prescribed psychotropic medication to address their mental disorders. ${ }^{224}$

Recent studies have reported that psychotropic medications are being prescribed for foster children at a higher rate than non-foster children. ${ }^{25}$ The U.S. Government Accountability Office ("GAO") conducted an exhaustive survey comparing the rate of psychotropic medication for foster and non-foster children in

216. Id.

217. See id. (explaining that prior to medication being administered involuntarily, a child sixteen or older or a parent or guardian has the right to request an administrative hearing).

218. See MD. CODE ANN., HEAlth-Gen. $\$ 10-708$ (West 2009) (“(b) Medication may not be administered to an individual who refuses the medication, except: (1) In an emergency, on the order of a physician where the individual presents a danger to the life or safety of the individual or others; or (2) In a nonemergency, when the individual is hospitalized involuntarily or committed for treatment by order of a court and the medication is approved by a panel under the provisions of this section.").

219. ARIZ. DEPT. OF HEALTH SERVS., supra note 196 (noting that a child sixteen years of age or older may refuse to consent to medication).

220. Id.

221. SOLCHANY, supra note 46 , at 3.

222. U.S. GOV'T ACCOUNTABILITY OFFICE, GAO-12-201, FOSTER CHILDREN: HHS GUIDANCE COULD HELP STATES IMPROVE OVERSIGHT OF PSYCHOTROPIC PRESCRIPTIONS 1 (2011) [hereinafter U.S. GAO, FOSTER CHILDREN] ("Children placed in foster care are among our nation's most vulnerable populations. Often having been removed from abusive or neglectful homes, they tend to have more numerous and serious medical and mental health conditions than do other children." (footnote omitted)).

223. Id at 5 .

224. Id. at 1 .

225. See $i d$. at 7 ("Foster children in each of the five selected states were prescribed psychotropic drugs at higher rates than were nonfoster children in Medicaid during 2008." (footnote omitted)). 
five states. 226 The ratio of foster children on psychotropic medication was between 2.7 and 4.5 times the rate for children not in foster care on Medicaid in 2008.227 In addition, the GAO study revealed that on average $28.8 \%$ of foster children received prescription medication, as compared to $7.64 \%$ of non-foster children in Medicaid $2008 .{ }^{228}$ This study also indicated increased likelihood of foster care children to have five or more psychotropic prescriptions than children outside of the system. ${ }^{229}$ This significant and alarming trend creates potential health risks. ${ }^{230}$

Several plausible explanations have been suggested for the high rate of foster children on psychotropic medications, ranging from greater exposure to trauma, ${ }^{231}$ frequent changes in foster placement, ${ }^{232}$ and varying state oversight policies. ${ }^{233}$ However, the significant and lopsided medication excesses of foster children may have other explanations, such as more opportunities of mental health professionals to come in contact with foster children, the desire to control and discipline foster children, and the ready access of physicians willing to prescribe psychotropic medication as a quick fix to a complicated and challenging problem.

In 2012, the GAO issued a Children's Mental Health report that looked closely at foster children. ${ }^{234}$ In the report, there is an acknowledgment that children removed from their parents due to parental violence, substance abuse, severe depression, or incarceration suffer significant traumatic stress. ${ }^{235}$ Such trauma "significantly increases the risk of mental health problems, difficulties with social relationships and behavior, physical illness, and poor school performance."236 Unfortunately, such traumatic stress symptoms are often identical to the symptoms that indicate other mental health conditions, which may lead to misdiagnosis and inappropriate treatments. ${ }^{237}$ Additionally, a state's child welfare agency is responsible for determining the child's living arrangement and often places the child in foster care, a group home, or a residential treatment center depending on the needs of the child. ${ }^{238}$ As such, foster children often experience frequent changes

226. See id. at 3 (explaining that data was reviewed from Florida, Massachusetts, Michigan, Oregon, and Texas).

227. Id. at 8 (as displayed in Appendix XVII, at $101-05$ ).

228. U.S. GAO, FOSTER CHILDREN, supra note 222, at 101-05.

229. Id. at 14 (reporting that "the rate of children prescribed five or more psychotropic drugs concomitantly ranged from 0.11 to 1.33 percent among foster children compared with a lower 0.01 to 0.07 percent rate among nonfoster children").

230. Id. (referring to the prescription of concomitant doses).

231. Id. at 10 (including greater emotional and behavioral issues and greater severity of mental health issues).

232. Id. at 11 (resulting in a lack of a consistent caretaker to plan treatment, offer consent, and provide oversight).

233. Id. at 12 (noting a lack of collaboration among state agencies, as well as the consent process for foster children, which may require the consent of multiple individuals or organizations).

234. U.S. GOV'T ACCOUNTABILITY OFFICE, GAO-13-15, CHILDREN'S MENTAL HEALTH: CONCERNS REMAIN ABOUT APPROPRIATE SERVICES FOR CHILDREN IN MEDICAID AND FOSTER CARE I (2012) [hereinafter U.S. GAO, CHILDREN'S MENTAL HEALTH].

235. Id at 14.

236. Id. at 15 .

237. Id.

238. Id. 
in their living placements that can lead to a lack of continuity in their mental health care. ${ }^{239}$ The frequent changes in residence lead foster children to have greater difficulty establishing relationships and bonding with adults, adding yet another stressor to these children. ${ }^{240}$

The American Bar Association ("ABA") Center on Children and the Law has also analyzed the challenges faced by foster children. ${ }^{241}$ Their report acknowledges that foster children often experience abuse and neglect, some witness violence and trauma, others face parents with their own profound mental health issues. ${ }^{242}$ Identified risk factors that increase these vulnerabilities include poverty, neighborhood violence, racial discrimination, lack of food, and homelessness. ${ }^{243}$ This begs the question: are these children prone to developing mental disorders, or are the traumatizing events in their lives creating the illusion of mental illness? Is it nature or nurture that accounts for the higher rate of mental illness diagnosis and subsequent prescriptions of isotropic medication?

The ABA report also expresses concern that foster children are more vulnerable to improper psychotropic medication. ${ }^{244}$ Factors that exacerbate such a situation include living in group-care, being hospitalized in psychiatric inpatient units, and being incarcerated. ${ }^{245}$ The ABA provides possible explanations for the higher use of psychotropic medication in this population, including that mental health professionals more frequently come in contact with these children in psychiatric treatment facilities, leading to greater opportunities to medicate. ${ }^{246} \mathrm{Also}$, children living in foster homes may be more susceptible to medication being used to control their behavior to avoid transfers to more restrictive settings, such as in group homes and residential training centers. ${ }^{247}$ There may also be pressure on social service agencies to keep children in less expensive foster home settings, and obedient behavior by foster children may result in the increased willingness of foster parents to continue caring for the children in their foster home. ${ }^{248}$ Whatever the reason, the overmedication of such vulnerable children is clearly alarming.

Various states have found children in foster care are medicated with psychotropic medication at higher rates. ${ }^{249}$ A Texas study revealed that foster

239. Id . at $\mathbf{n} .55$ (finding that foster children moved an average of 1.6 times in an eighteenth month period, with some children changing placements as many as twelve times in the same period).

240. U.S. GAO, CHILDREN'S MENTAL HEALTH, supra note 234, at 15.

241. SOLCHANY, supra note 46 , at 1 .

242. Id. at 3.

243. Id. ("Regardless of what led to their involvement in the child welfare system, all face separation, broken relationships, and confusion.").

244. Id. at 14 .

245. Id. (citations omitted).

246. $I d$.

247. See SolChANY, supra note 46 , at 14 (describing generally how "children in foster care are vulnerable to inappropriate or excessive medication use").

248. See id. at 4 (cautioning that "if caregivers are not adequately trained and educated in caring for a child with significant emotional and psychological needs, medications can often be given to the child to 'manage their behaviors' rather than to truly treat the child's illness").

249. See U.S. GAO, Foster CHILDREN, supra note 222, at 8 ("Foster children in Florida, Massachusetts, Michigan, Oregon, and Texas were prescribed psychotropic drugs at rates 2.7 to 4.5 times higher than were nonfoster children in Medicaid in 2008."). 
children enrolled in Medicaid were 3.5 to 11 times as likely to receive psychotropic medication than other children enrolled on Medicaid ${ }^{250}$ The study revealed other alarming data among the foster children receiving psychotropic medication: $41.3 \%$ received three or more different classes of drugs and $15.9 \%$ received four or more different classes of drugs. ${ }^{251}$ The most frequently used medications were antidepressants (56.8\%), attention-deficit/hyper activity disorder drugs (55.9\%), and anti-psychotic agents $(53.2 \%) .{ }^{252}$ This alarming concomitant use raises many questions as to the necessity of this approach. According to testimony of Julie Magno Zito before the House of Representatives Ways and Means Committee in May $2008,{ }^{253}$ there is little evidence of effectiveness or safety in the concomitant psychotropic medication patterns for children in foster care. ${ }^{254}$ Professor Zito recommended individualized patient record review when three or more psychotropic medication classes are given to children concomitantly. ${ }^{255}$ Her report also highlighted the recommendation from the American Academy of Child and Adolescent Psychiatry ("AACAP"), calling for more frequent monitoring of the health care status of children in foster care placement than for children residing in stable homes with parents. ${ }^{256}$

The National Survey of Child and Adolescent Well-Being ("NSCAW") examined the use of psychotropic medications for children in foster care through the child welfare system. ${ }^{257} \mathrm{~A}$ striking finding is the disparity of psychotropic medication use rates when children are placed in-home versus out-of-home, at $11 \%$, and $17.7 \%$, respectively. ${ }^{258}$ The high rate of medication use in out-of-homeplacements should concern all providers of child welfare services to children in the foster care system. The findings of this study suggest that entry into foster care serves as a "gateway for children to access specialty mental health services." 259 Such entry tends to increase the child's likelihood of receiving psychopathic treatment. ${ }^{260}$

The Administration for Children and Families of the U.S. Department of

250. Zito et al., supra note 1 , at el 57.

251. Id

252. Id.

253. See Prescription Psychotropic Drug Use Among Children in Foster Case: Hearing Before the Subcomm. on Income Security and Family Support of the H. Comm. on Ways and Means, 110th Cong. (2008) (statement of Julie M. Zito, Professor of Pharmacy and Psychiatry, Pharmaceutical Health Services Research, University of Maryland, Baltimore).

254. Id. at 9 .

255. Id. at 10.

256. Id. at 12 .

257. See leyla F. Stambaugh et al., National Survey of Child and Adolescent WellBeing, No. 17, Psychotropic Medication USE by Children IN ChILd Welfare 1-2 (2012) (involving a longitudinal study of the well-being of 5873 children involved in the child welfare system for a 14-month period starting in February 2008).

258. Id. at 3 .

259. Id. at 6

260. Cf. Susan dosReis et al., Mental Health Services for Youths in Foster Care and Disabled Youths, 91 AM. J. PUB. HEALTH 1094, 1094 (2001) (concluding that youths in foster care and youths receiving Supplemental Security Income use more mental health services and are prescribed psychotherapeutic medications more than youths in other aid categories). 
Health and Human Services ("HHS") also released an Information Memorandum focused on oversight of psychotropic medication use in foster children. ${ }^{261}$ Though psychotropic medication usage among foster children is particularly distressing, rates of psychotropic medication use among all children have increased. ${ }^{262}$ A study of psychotropic medication use in children revealed that "[b]etween 1996-1999 and 2004-2007, there was an approximately $75 \%$ increase in the proportion of child and adolescent visits that mentioned a psychotropic medication (from $6.0 \%$ in 19961999 to $10.6 \%$ in 2004-2007). ${ }^{263}$ A plausible explanation for this increase is the efforts of pharmaceutical companies to market drugs to prescribers and consumers. ${ }^{264}$ This practice risks damage to the integrity of the psychiatric profession. ${ }^{265}$ With the increase in prescribing psychotropic medication for children due to pressures from the pharmacy lobby, are our children receiving significant increases in diagnoses of mental illness for the purpose of selling and distributing more psychotropic medication to them? Are children's mental health needs being dictated by the pharmaceutical industry?

Children's use of antipsychotic medication has also seen an increase in recent years. ${ }^{266}$ There has been a worrying surge in the use of antipsychotic medication being prescribed off-label. An off-label prescription is where medication is prescribed for conditions and in populations that are not included in FDA-approved labels. ${ }^{267}$ Off-label prescriptions create safety concerns, including the possibility of receiving ineffective medication, receiving dosages that are too high or too low, or presenting side effects that are unique to children. ${ }^{268}$ Not surprisingly, in 2007 , children on Medicaid who were in foster care were prescribed antipsychotic medication at a significantly higher rate than non-foster children on Medicaid. ${ }^{269}$ Of particular concern to the GAO is the realization that drug manufacturers do not always test medications for use on children, and that physicians can prescribe these medications off-label to children. ${ }^{270}$

261. Memorandum from the Admin. for Children \& Families, U.S. Dep't of Health \& Hum. Servs. on the oversight of Psychotropic Medication for Children in Foster Care (Apr. 11, 2012), available at http://www.acf.hhs.gov/programs/cb/resource/im1203.

262. U.S. GAO, ChILDREN'S MENTAL HEALTH, supra note 234, at 10.

263. Jonathan S. Comer et al., National Trends in Child and Adolescent Psychotropic Polypharmy in Office-Based Practice, 1996-2007, 49 J. AM. ACAD. CHILD. \& ADOLESCENT PSYCHIATRY 1002, 1005 (2010).

264. John Walkup et al., Practice Parameter on the Use of Psychotropic Medication in Children and Adolescents, 48 J. AM. ACAD. CHILD. \& ADOLESCENT PSYCHIATRY 961, 962 (2009).

265. See Leemon McHenry, Ethical Issues in Psychopharmacology, 32 J. MED. ETHICs 405, 409 (2005) ("The integrity of medicine is endangered by an industry that profits from illness and distorts the process of scientific inquiry by marketing strategy, public relations campaigns, and the sheer power of buying influence in high places.").

266. U.S. GAO, CHILDREN's MENTAL HEALTH, supra note 234, at 2.

267. See Stephen Crystal et al., Broadened Use of Atypical Antipsychotics: Safety, Effectiveness, and Policy Challenges, 28 HEALTH AFFaIRS w770, w773 (2009) (finding that, in 2004, almost $75 \%$ of "children enrolled in Medicaid who were taking antipsychotic medication were diagnosed with conditions for which there was no FDA indication").

268. Susan thaul, Cong. Research Serv., Rl33986, FDA's authority to Ensure That DRUGS PRESCRIBED TO ChILDREN ARE SAFE AND EFFECTIVE 3 (2012).

269. U.S. GAO, CHILDREN'S MENTAL HEALTH, supra note 234, at 12.

270. Id. at 12-13. 
In particular, the extremely high use of antipsychotic medication for children on Medicaid, which is twice the rate for privately insured children, ${ }^{271}$ revealed other troubling findings. Many children who took antipsychotic medication did not receive other mental health services, such as psychosocial therapy or counseling, within that same year. ${ }^{272}$ The AACAP acknowledges that medication alone is rarely an adequate treatment for children with complex mental health needs. ${ }^{273}$ The overreliance on psychotropic medication for children and the lack of face-to-face professional mental health counseling services is another indictment of the mental health system for children. ${ }^{274}$ Oversight for the administration of psychotropic medication to children is badly needed, and is beginning to be called for by government agencies and oversight committees. ${ }^{275}$ Social service agencies, mental health agencies, and federal and state funding sources should coordinate their efforts to remedy the catastrophe that has fallen upon children in the mental health care system, particularly upon the vulnerable foster care population. ${ }^{276}$

\section{B. An Oversight System Should be Created to Monitor the Children's Mental Health System}

Greater scrutiny is warranted for the instances where a government agency, usually a local department of social services, becomes involved in the removal of children from parents due to allegations of abuse, neglect, or abandonment. This need for oversight is demonstrated by the overmedication of these vulnerable children. A cautious approach when a local government social service agency intervenes is not unusual. In Maryland, an application by a parent or guardian on behalf of a child for admission into a psychiatric in-patient facility is permissible. ${ }^{277}$ When the child is in the care of a social service agency, however, the voluntary application process is prohibited. Application for admission to such a facility by a minor in foster care under a social service agency is limited to the involuntary admissions process. ${ }^{278}$ Having more stringent oversight and more stringent judicial authority over these decisions is based in part on the historical concern that social

271. See id. at 19 (finding that, overall, " $1.3 \%$ of children in Medicaid and $0.5 \%$ of privately insured children took antipsychotics" and that the majority of children who took an antipsychotic were males ages six to seventeen).

272. Id.

273. Id.

274. See id. at 37 "'Our analysis of national survey data indicates that concerns raised by providers, children's advocates, and others about potentially inappropriate prescribing of psychotropic drugs for some children and a lack of needed mental health services for some children may be warranted.").

275. See Fostering Connections to Success and Increasing Adoptions Act of 2008, 2008 Cal. Stat. 110-351 (calling for health care service oversight for children in foster care including oversight of prescription medications); see also U.S. GAO, CHILDREN'S MENTAL HEALTH, supra note 234, at 29.

276. See U.S. GAO, ChILdREN's MENTAL HEALTH, supra note 234, at 37 ("Nonetheless, these findings do suggest that the recent federal and state initiatives to improve monitoring and oversight are appropriate, and that continued assessment of the prescribing of psychotropic medications to vulnerable populations and of the receipt of mental health services is important.").

277. MD. CODE ANN., HEALTH-GEN. § 10-610(c)(4)(ii) (West 2009).

278. See $\S 10-613$ (establishing that admissions of minors to state facilities are involuntary admissions unless otherwise provided for under Part II of the statutes). 
service agencies may abuse the voluntary admissions process out of convenience rather than based on mental health needs for such in-patient care or treatment. Such additional burdens and requirements appear justified for the vulnerable foster care population, both in terms of in-patient hospitalization as well as the prescribing of psychotropic medication to these children.

Due to the documented overmedication of foster children, as well as the increasing use of psychotropic medication to treat mentally ill children in general, there is growing demand for improved patient, family, and caregiver education, governmental oversight, and provider reporting. AACAP makes the following recommendations for the use of psychotropic medication with children and teens: ${ }^{279}$

1. Before initiating pharmacotherapy, a psychiatric evaluation is completed;

2. Before starting pharmacotherapy, a medical history is obtained, and a medical evaluation is considered when appropriate;

3. The prescriber is advised to communicate with other professionals involved with the child to obtain collateral history and set the stage for monitoring outcome and side effects during the medication trial;

4. The prescriber develops a psychosocial and psychopharmacological treatment plan based on the best available evidence;

5. The prescriber develops a plan to monitor the patient, short and long term;

6. Prescribers should be cautious when implementing a treatment plan that cannot be appropriately monitored;

7. Prescriber provides feedback about the diagnosis and educated the patient and family about the child's disorder, and the treatment and monitoring plan;

8. Complete and document the assent of the child and the consent of the caregivers before initiating medication treatment and at important points during treatment;

9. The assent and consent discussion focuses on the risks and benefits of the proposed alternative treatments;

10. Implement medication trials using an adequate dose and for an adequate treatment period;

11. The prescriber reassesses the patient if the child does not respond to the initial medication trial as expected;

12. The prescriber needs a clear rationale for using medication combinations;

13. Discontinuing medication in children requires a specific plan.

The AACAP recommendations include significant guidance on the need to obtain assent of the child and consent of the caregivers before initiating medication treatment, including the provision of risks and benefits as well as alternative treatments. ${ }^{280}$ The acknowledgment that both the child and caregiver are meaningful participants in the conversation with the prescriber of the psychotropic

279. John Walkup et al., Practice Parameter on the Use of Psychotropic Medication with Children and Adolescents, 48(9) J. AM. ACAD. CHILD. ADOLESCENT PSYCHIATRY 961-973 (2009).

280. Id. at 967. 
medication is to be applauded. ${ }^{281}$ In addition, the recognition that combining medications increases the risks to the child is an important admonishment that must be recognized by all parties. ${ }^{282}$

Another important study examined the use of psychotropic medication of children in state custody. ${ }^{283}$ The data revealed that state and county welfare agencies have established a variety of means of providing consent for prescribing psychotropic medication. ${ }^{284}$ Of particular interest is the finding that court consent is required prior to administering psychotropic medication to children in six states; with judicial consent required prior to an antipsychotic being prescribed in residential treatment centers in Massachusetts. ${ }^{285}$ Although Massachusetts limits its court procedure to specific antipsychotic medication, such an approach of court authorization may be necessary to stem the tide of the troubling increase in medication among the foster care population. ${ }^{286}$ States should consider requiring court approval prior to the administration of psychotropic medication to children admitted into inpatient psychiatric hospital settings. ${ }^{287}$ At the same time a judge approves the admission of foster children in psychiatric hospital settings, a concurrent finding of approval or denial of the administration of psychotropic medication should occur. ${ }^{288}$ Such judicial oversight for the foster care population into the most restrictive hospital settings ensures greater oversight that should lead to a decline in the psychotropic medication use of foster children. ${ }^{289}$ Hopefully, alternative treatment plans, second opinions, and independent oversight will occur

281. See Laurel K. Leslie et Al., Tufts Clinical and Translational SCi. InST., Multi-State STUdy ON PSyChOTROPIC MEDICATION OVERSIGHT IN FOSTER CARE 13-15 (2010) (describing the challenges faced by states in the informed consent and treatment decision-making processes, and the various solutions implemented, which include greater participation by the child).

282. See U.S. GAO, ChILDREN'S MENTAL HEALTH, supra note 234, at 1-2 ("In addition, child mental health advocates, providers, and researchers have expressed concern about the increase in the prescribing of psychotropic medications for children, in part because there is limited evidence available regarding short- and long-term safety and efficacy for some types of medications, particularly for combinations of medications.").

283. See Naylor, supra note 58, at 175 (examining the means in which state and county child welfare agencies provide consent for providing psychotropic medicine to youths in state custody).

284. Id. at 182 .

285. Id.

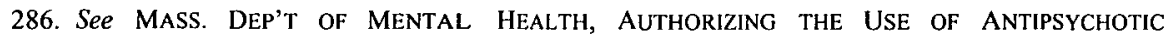
MEDICATIONS: QUESTIONS AND ANSWERS (describing a Massachusetts Rogers Guardianship and its limitations); see also Joanne Moses, What is a Rogers Guardianship?, http://www.massguardianshipassociation.org/information/guardianship-of-an-adult-2/rogers-

guardianship/ (last visited Oct. 27, 2013) (describing the types of treatment a court may consider). A Rogers guardianship hearing is where "the court is being asked to authorize extraordinary treatment or care, such as administering antipsychotic medications, admitting an adult to a nursing home facility, and other medical care." Id.

287. See MASS. Dep't of MENTAL HEALTH, supra note 286 (describing how a judge decides treatment by acting as substitute decision maker for Rogers Guardianships).

288. See Moses, supra note 286 (describing a Rogers guardianship hearing).

289. See Dependent Children, Psychotropic Medications: Hearing on A.B. 82 Before the S. Comm. on Judiciary, 2009 Leg., 2009-2010 Reg. Sess., at 1 (Cal. 2009) ("In 1999, the [California] Legislature passed SB $543 \ldots$ in response to concerns that foster children were being subjected to excessive use of psychotropic medication, and that judicial oversight was needed to reduce the risk of unnecessary medication."). 
when courts are required to approve psychotropic medications. ${ }^{290}$

In addition, state monitoring of the use psychotropic medication is necessary. ${ }^{291}$ Florida, Arizona, and Texas have oversight programs that are highlighted in the Naylor study. ${ }^{292}$ The need for "[a]n effective centralized psychotropic medication consent and oversight process also requires appropriate enabling state legislation to establish who is capable of and responsible for consenting for treatment for youth in state care" for proper consent protocols is also recommended in the Naylor report. ${ }^{293}$

In an exhaustive and comprehensive study, the Tufts Clinical and Translational Science Institute examined policies and practices concerning state oversight of psychotropic medication for children in foster care. ${ }^{294}$ The study begins by acknowledging that over the past decade, psychotropic medication use in youth (defined as ages two to twenty-one years) has increased two-three fold, and concomitant use of psychotropic medication has increased 2.5-8 fold. ${ }^{295}$ The explanations offered for the increase in the use of psychotropic medications among youth in foster care include the demand by foster parents and schools, reimbursement and time pressures in the health care system, how Medicaid will pay for the medications, how school officials' need to control a child's behavior before permitting the child to return to school, and pressure from foster parents to decrease a child's behavioral issues to keep the child in the foster care home. ${ }^{296}$

The Tufts study also identified "red flag" markers that states used to identify safety and equality of care issues. ${ }^{297}$ The most common red flags include use of psychotropic medication in young children, use of multiple psychotropic medications concomitantly (usually three to five medications), dosage exceeding current maximum recommendations, or dosage that are not consistent with state guidance, and the failure to document or discuss the risks and benefits of the

290. See U.S. GAO, CHILDREN's MENTAL HEALTH, supra note 234, at 24 (concluding that the state of Washington's Second Opinions program resulted in an increase in referrals for psychosocial therapy and a decrease in prescribing of antipsychotic medications); LESLIE ET AL., supra note 281, at 13 (listing states' solutions to problems with informed decision-making/consent and appropriate medication monitoring for foster care youth, which included the formulation of second opinions for complex cases).

291. See Naylor, supra note 58, at 186-87 ("A psychotropic medication consent program that provides effective longitudinal oversight of a youth's care, monitoring of prescribing patterns, and consultative and educational services for foster parents, childcare workers, and caseworkers has several potential benefits.").

292. See id. at 184 (noting that Florida provides an update to the court regarding the child's medical and behavioral status, Arizona offers guidelines for prescribing psychotropic medication to children, Texas established a panel of child and adolescent psychiatrists, psychologists, and other mental health professionals to develop best practice guidelines).

293. Id. at 187.

294. LESLIE ET AL., supra note 281 , at 1.

295. See id. (additionally finding that "[e]stimated rates of psychotropic medication use for youth in foster care . . . are much higher (ranging from 13-52\%) than those for the general youth population (4\%)" (footnotes omitted)).

296. Id. at 4.

297. Id. at 7 (explaining that red flag markers are used by states in their audits and case reviews, resulting in promoting case reviews, ordering lab work, initiating prior authorization, and identifying individual prescriber outliers). 
medications. ${ }^{298}$

State oversight systems, as highlighted in the Tufts report, include such components as access to up-to-date guidelines on clinical practices, informed decision-making and consent and appropriate medication monitoring for individual youth in foster care, involvement of biological parents and youth in ongoing decision-making, oversight programs for monitoring trends and a national approach and resources for psychotropic medication oversight. ${ }^{299}$ States vary considerably about who has the authority to give informed consent. ${ }^{300}$ This reflects the rather complex and challenging issue of who is granted the authority to consent to the prescribing of psychotropic medication to foster children.

Three suggestions are offered to address the prescribing of psychotropic medication to foster children. ${ }^{301}$ First, children age sixteen years and older should be permitted to consent or refuse the administering of psychotropic medication. Second, for foster children hospitalized in a psychiatric setting, an administrative law judge should conduct a hearing concurrently with the hearing on the administration into the psychiatric facility to authorize the administration of psychotropic medication. Third, a state oversight program should be created to monitor and track the prescribing of psychotropic medication of foster care children. Whenever more than one psychotropic medication is prescribed, the oversight program shall be notified immediately.

\section{Psychotropic Medication for Children is No Magic Bullet}

In his accomplished book, Anatomy of an Epidemic, Robert Whitaker rails against the psychiatric and pharmacological industry that he claimed has given rise to mental illness in America. ${ }^{302}$ Whitaker challenges the conventional wisdom that

298. Id.

299. LESLIE ET AL., supra note 281 , at 8.

300. See id. at 14 (explaining that in two states, the authority is with the prescriber, foster parent, and youth; in other states the authority lies with the child welfare agency; some states use an external agency for expert review; two states use the court system).

301. See Tenn. Dep'T Child. Serv., Administrative Policies and Procedures: 20.24, 5 (2011) available at http:/www.state.tn.us/youth/dcsguide/policies/chap20/20.24.pdf ("When the need for psychotropic medication arises, the parent(s) should be engaged in all medication decisions and appointments for the child, unless ... the youth is 16 years of age or older."); see N.Y. MENTAL HYG. $\S$ 33.21(e)(2) (McKinney 2011) ("A minor sixteen years of age or older who consents may be administered psychotropic medications without the consent of a parent or guardian or the authorization of a court ... ."); Moses, supra note 286 ("However, a Guardian does not have the power to consent or withhold consent for the use of antipsychotic medications for their Incapacitated Person. A special procedure is required to protect the Incapacitated Person. If the Incapacitated Person is being treated with, or it is being proposed to treat this person with antipsychotic medications, the guardian must obtain court authorization at a court hearing. If the Court authorizes such treatment, it will issue an order called a "Rogers" order for treatment with antipsychotic medication."); George H. Sheldon et al., Letter to State Directors of Child Welfare, ADMIN. FOR CHILD. \& FAM., U.S. DEP'T OF HEALTH \& HUM. SERV., $2-$ Nov. 23, 2011), https:/www.childwelfare.gov/systemwide/mentalhealth/effectiveness/jointlettermeds.pdf (outlining steps that can be taken by state child welfare agencies to improve psychotropic medication oversight).

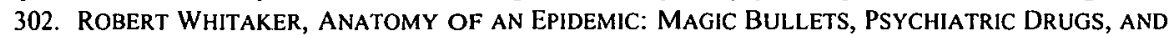
THE ASTONISHING RISE OF MENTAL ILLNESS IN AMERICA 5 (2010) ("[A]s the psychopharmacology 
mental illness is a result of chemical imbalances in the brain and that psychotropic medication can improve a person's mental health. ${ }^{303}$ Whitaker asserts that the precise causes of mental health are unknown. ${ }^{304} \mathrm{He}$ argues that psychiatrists embraced the chemical imbalance theory of mental disorders "because it set the stage for them to become real doctors." ${ }^{305}$ As doctors of internal medicine have antibodies, now psychiatrists could have their "anti-disease" pills too. ${ }^{306}$

There is a growing chorus of voices ringing the iatrogenic process bell, asserting that doctors, through their choice of medical treatment, inadvertently induce mental illness. ${ }^{307}$ Yale psychiatrist Thomas McGlashan questioned whether antipsychotics were making patients "more biologically vulnerable to psychosis" and wondered whether the cure was worse than the disease. ${ }^{308}$ Whitaker warns that antipsychotic medication may actually make some patients with the diagnosis of schizophrenia more "vulnerable to future relapses than would be the case in the natural course of the illness." 309 Whitaker asserts "drugs were escalating the likelihood that a person who suffered a psychotic break would become chemically ill." ${ }^{310} \mathrm{He}$ follows that initial exposure to neuroleptics puts patients on a path to lifelong drug dependence ${ }^{311}$ and relapse suffered by patients withdrawn from antipsychotics were drug-related and not the result of the disease. ${ }^{312}$

Whitaker also focuses his outcry on the impact the use of psychotropic medication has on children. ${ }^{313}$ When Prozac, an antidepressant, was introduced, "[t]he percentage of children so medicated tripled between 1988 and 1994, and by 2002 , one in every forty children under the age of nineteen in the United States was taking an anti-depressant." 314 In addition, the number of children discharged from hospitals with a bipolar diagnosis rose fivefold between 1996 and 2004, striking one in every fifty prepubescent children in America. ${ }^{315}$ According to Whitaker, this epidemic came of age; with the rise is lockstep with the prescribing of stimulants and antidepressants to children. ${ }^{316}$

The iatrogenic epidemic, reports Whitaker, accounts for " 400,000 bipolar children arriving via the ADHD doorway, and at least another half million through

revolution has unfolded, the number of disabled mentally ill in the United States has skyrocketed. Moreover, this increase in the number of disabled mentally ill has accelerated further since the introduction of Prozac and the other second-generation psychiatric drugs").

303. Id. at 10-11.

304. Id. at 332.

305. Id. at 78 (internal quotation marks omitted) (citation omitted).

306. Id.

307. See id. at 71-85 (describing the evidence that chemical imbalances in the brain cause mental health problems, such as depression and schizophrenia, and that medications designed to treat these supposed imbalances induce the problems that the medications were designed to treat).

308. WHITAKER, supra note 302 , at 114.

309. Id. at 104 (citation omitted).

310. Id.

311. Id. at 106 .

312. Id.

313. Id. at 216-17.

314. WHITAKER, supra note 302, at 229.

315. Id. at 235.

316. Id. 
the antidepressant doorway." 317 Whitaker notes that foster children are now regularly diagnosed with bipolar disorder, their symptoms not the result of having been born into dysfunction, but "rather due to biological illness." $318 \mathrm{He}$ also asserts that teenagers involved in the criminal justice system are "regularly funneled into psychiatric roles," adding to the bipolar numbers. ${ }^{319}$ Even the very young child is affected; the number of severely mentally ill children under six years of age receiving Supplemental Security Income ("SSI") has tripled, recently rising from 22,452 in 2000 to 65,928 in $2007 .{ }^{320}$ An alarming piece of data reported by the GAO in 2008 is that one in every fifteen young adults, ages eighteen to twenty-six, and is now "seriously mentally ill." 321 Whitaker shines the spotlight directly on the misuse of the prescribing of psychiatric drugs to children and adolescents over the past twenty years, which has become so commonplace that it is putting "millions [of children] onto a path of lifelong illness." 322 There must be a dialogue within the psychiatric, social work, and legal communities to explore alternative forms of nondrug treatment options and recognize the limits of medication in the treatment of mental illness. ${ }^{323}$ The speed at which physicians tend to diagnose children with mental illness, often during the initial examination of the child, leads to a lifetime label and lifetime of medication and must be the centerpiece of a reform movement. ${ }^{324}$

\section{STATISTICAL REVIEW AND ANALYSiS OF PSYCHIATRISTS AND PEDIATRICIANS' VIEWS ON CONSENT, REFUSAL, AND MEDICATION OF MINORS}

The empirical data provided in this article is submitted to demonstrate the views and opinions of psychiatrists and pediatricians who treat mentally ill children with psychotropic medication. To provide empirical data on the perspective of psychiatrists and pediatricians about the consent procedures for children, and procedures governing a minor's refusal to take psychotropic medication, this author surveyed a diverse group of thirty-five psychiatrists and pediatricians. ${ }^{325}$ The

317. Id. at 239; see id. at 242 (explaining how "[f]ifty years ago, physicians virtually never saw manic-depressive illness in preteens"; however, after physicians started prescribing Ritalin to hyperactive children, there were reports of manic children).

318. Id. at 242.

319. WHITAKER, supra note 302, at 242; see id. at 245 (noting that a child who is hyperactive or depressed is treated with a drug that triggers a manic episode and becomes a child put on a drug cocktail, leading to a lifetime of disability).

320. Id. at 245 .

321. Id. at $245-46$.

322. Id. at 246 .

323. See id. at 331-59 (calling for a conversation about the role of psychotropic medications, a reformed mental health care system, and new treatments for mental health concerns).

324. See WHITAKER, supra note 302, at 220, 224, 234-37, 246 (discussing the rapid rise in the number of children diagnosed with ADHD and bipolar disorder over the past few decades and the likelihood that the medications used to treat such conditions only cause worse mental health problems).

325. See Donald H. Stone, Children \& Psychotropic Medications: Psychiatrists (2013) [hereinafter Stone Survey] (unpublished web-based survey conducted by the author), available at https://www.surveymonkey.com/s.aspx?sm=q3I\%2bAQzUkEF\%2fnkHnVSW9Hw\%3d\%3d. The survey questions are listed in Appendix B. 
respondents to the survey were psychiatrists or pediatricians from a variety of settings, public and private, inpatient and outpatient. ${ }^{326}$ The survey highlighted the treatment and consent issues involving children in the foster care system, which revealed an important perspective surrounding the reasons for the overmedication of foster care children. ${ }^{327}$ The empirical data ${ }^{328}$ contained in this article is submitted to serve as a backdrop for purposes of illuminating and understanding the consent issue, medication refusal issues, as well as the challenges in prescribing psychotropic medication for minors.

When mentally ill children are removed from their parent and placed in the care of a social service agency and treated in an inpatient psychiatric facility, there is a need to provide informed consent for psychotropic medication. ${ }^{329}$ There is an even split between consent provided by the parent and consent provided by a social services caseworker. ${ }^{330}$ On the one hand, a child removed from their home due to abuse or neglect may trigger a need for a substitute decision maker; on the other hand, the social service agency may desire to keep the parent involved by permitting them to continue to make treatment decisions. ${ }^{331}$

At the time physicians prescribe psychotropic medication to children and prior to obtaining informed consent, certain information regarding the psychotropic medication is provided to the party giving consent. The survey inquired about a variety of information about the medication to enable the person providing consent to understand the options and reasons for medication in order to provide an informed and knowledgeable consent prior to the medication being administered. Of the thirteen items included, the top three areas of information include adverse reactions, benefits and intended outcomes, and diagnosis and targeting symptoms. ${ }^{332}$ The least likely information offered include: explanation of procedure if consent is not obtained, FDA status of the medication, and frequency range. ${ }^{333}$

326. Id.

327. Id.

328. Id. The percentage cited in this article represents the percentage of valid responses to each question, which exclude participants who did not respond.

329. Naylor, supra note 58, at 179-80.

330. See Stone Survey, supra note 325 , at Question 4 (noting that when an emergency exists, the informed consent process is overridden by the physician).

331. See Naylor, supra note 58, at 176, 179-83 (noting that states have established various consent procedures involving either parents or government officials for children in state custody).

332. Stone Survey, supra note 325, at Question 5.

333. Id. at Question 5. 


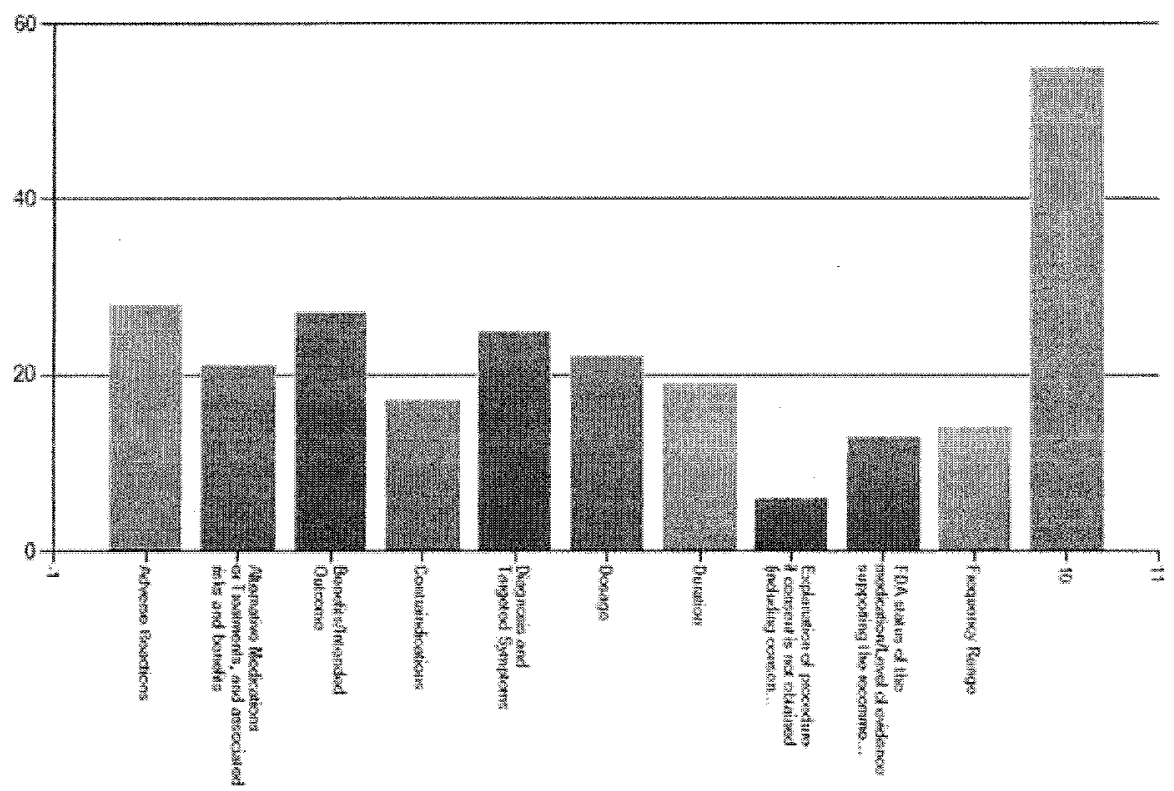

The respondents were asked whether they utilize a standardized consent form prior to prescribing a psychotropic medication to a minor. ${ }^{334}$ Eighty-one percent answered no. It is strongly recommended that a standardized consent form be utilized, including the important criteria as highlighted in Survey Question 5. A model standardized consent form is included in Appendix B.

Another important issue included in the survey involves the procedure to override a minor's refusal to take psychotropic medication while a patient is in an inpatient facility. In several states, state law dictates the procedure for overriding a minor's refusal. ${ }^{335}$ In some states, a parent or legal guardian is called upon to consent to psychotropic medication and the voice and opinion of the minor is disregarded. ${ }^{336}$ However, there is a growing sentiment for mature minors, at age sixteen and above, to be consulted and heard on the matter of psychotropic medications. ${ }^{337}$ When a minor at age sixteen refuses to consent to psychotropic medication at an inpatient facility, the procedure for overriding such minor should be the same as that one which is utilized for adult psychiatric inpatients and which is spelled out in state law. ${ }^{338}$ It is urged that the same procedure followed for adults

334. Id. at Question 6.

335. See, e.g., ARIz. DePT. OF HEALTH SERVS., supra note 196

336. See John A. Menninger, Involuntary Treatment: Hospitalization and Medications 5, available at http://www.brown.edu/Courses/BI_278/Other/Clerkship/Didactics/Readings/INVOLUNTARY\%20TRE ATMENT.pdf (unpublished manuscript) (explaining that parents, regardless of their children's wishes, typic

ally have the right to consent to their children's medical procedures).

337. See Christopher O'Connor, What Rights Do Minors Have to Refuse Medical Treatment?, $4 \mathrm{~J}$. LANCASTER Gen. HosP. 63, 63-64 (2009), available at http://www.jlgh.org/Past-Issues/Volume-4--Issue-2/Medico-Legal-Matters.aspx (noting that physicians often wish to respect the privacy rights of minors by allowing them to make their own medical decisions).

338. See, e.g., Md. Code AnN. Health-General $\S 10-708$ (West 2009) (allowing an adult in 
who refuse psychotropic medication be expanded to minors at age sixteen and above. ${ }^{339}$ The Survey solicited views on this logic, including who participates when minors refuse; the most often mentioned individuals include the treating psychiatrist, social services case worker, and parent or guardian. ${ }^{340}$

In an in pation setting. What stops to you wat if minor rofuses to tak a preserbad psychotrople medication? check all that apply.

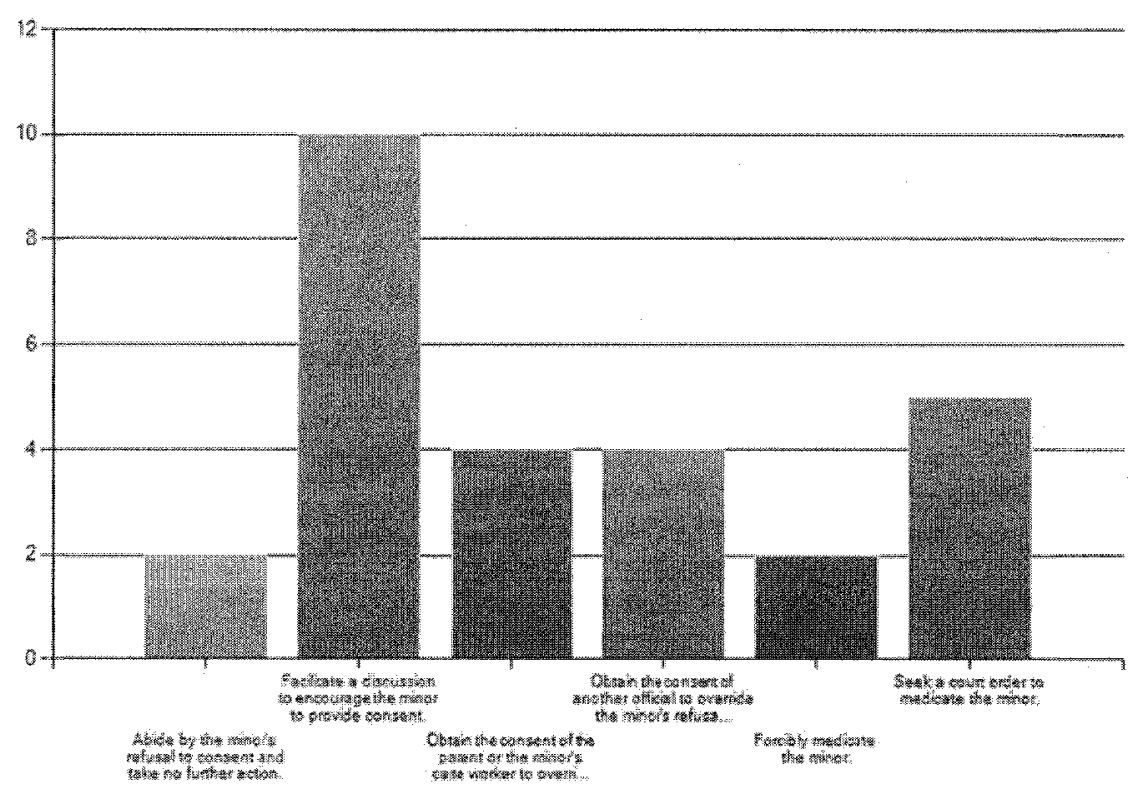

Maryland to refuse medication unless the individual is either in the midst of an emergency situation or has been voluntarily committed and the medication has been approved by a clinical review panel).

339. See id. (defining the process by which adults in Maryland may refuse mental health medication).

340. Stone Survey, supra note 325, at Question 10. 
When psychiatrists and physicians were asked for their opinion as to at what age a minor should have the right to refuse the administration of a psychotropic medication, age sixteen and above was the most common response. ${ }^{341}$

In your opinion, should a minor have the right to refuse the sdministration of a psychotropic medication? If so, should that right be timited by the age of the minor?

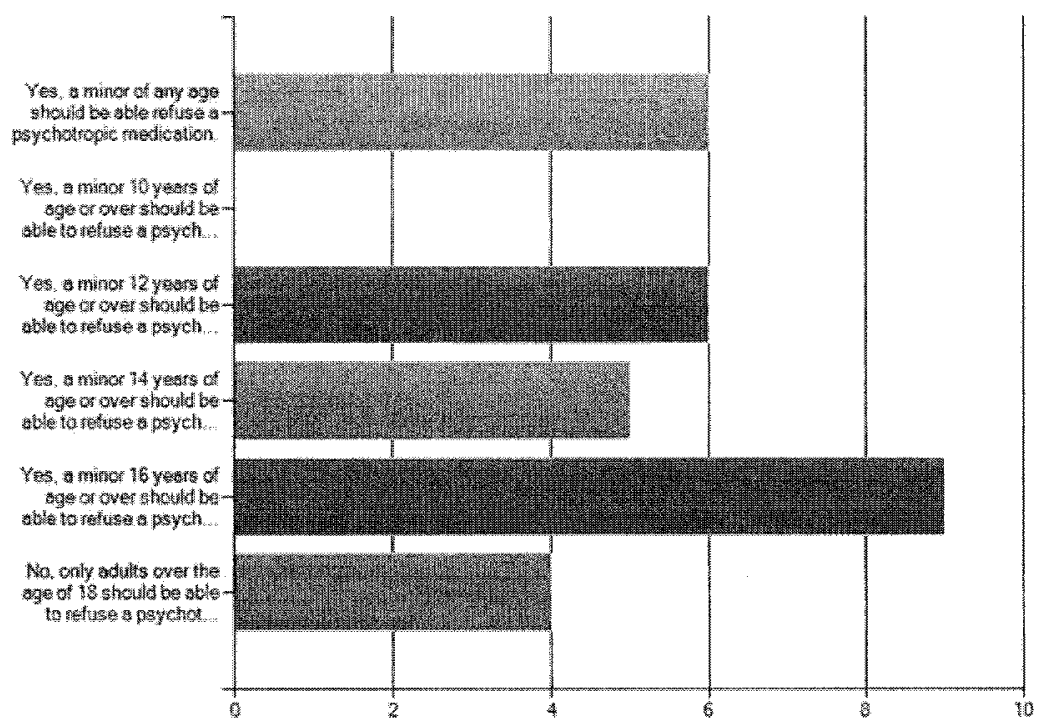

341. Id. at Question 13. 
The procedure for overriding a minor's refusal to consent to psychotropic medication should be resolved by an independent judicial hearing rather than by a process seen by the hospital, recommending the independent system two to one. ${ }^{342}$

In your opinion, who should govem the procedure overriding a minor's refusal to consent to asychotropic medications?

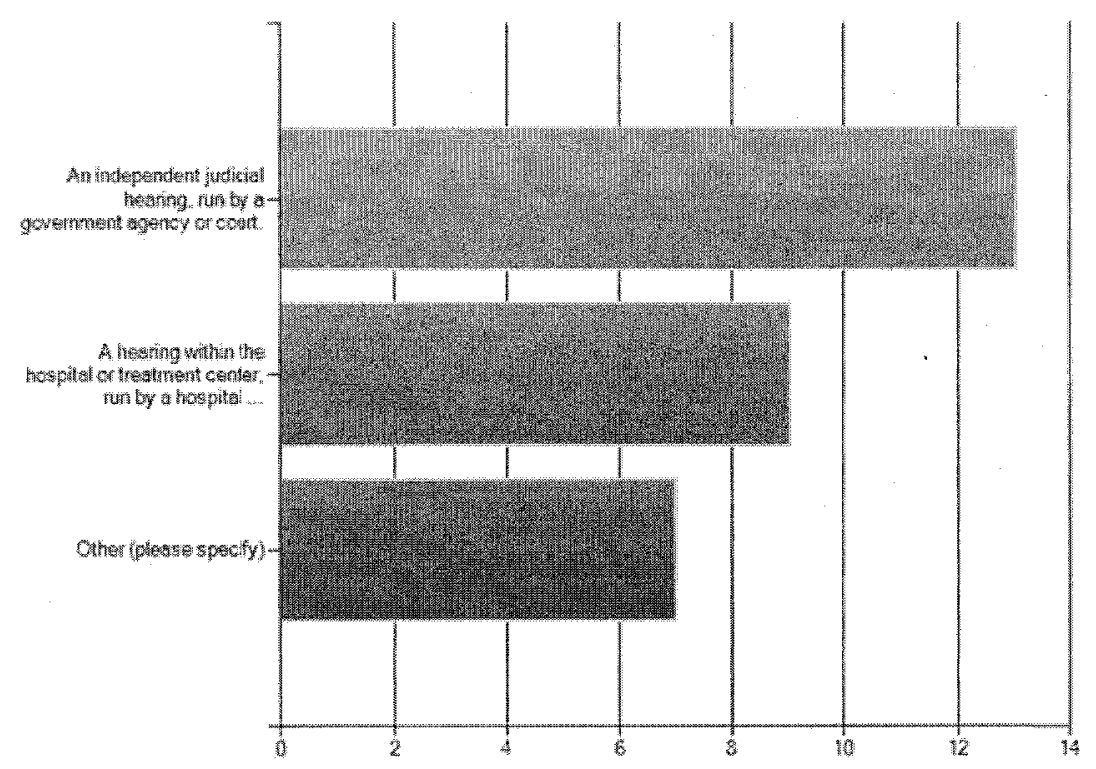

342. Id. at Question 14 
Another controversial issue surveyed addressed the question of whether the treating physician prescribing the psychotropic medication relied on a list of approved medications for use on minors. ${ }^{343}$ Rather surprisingly, eighteen of twentyseven answered no. ${ }^{344}$

Do you rely on allst of approved psychotropic medications for use in minors? If so, who provides this list? Check all that apply.

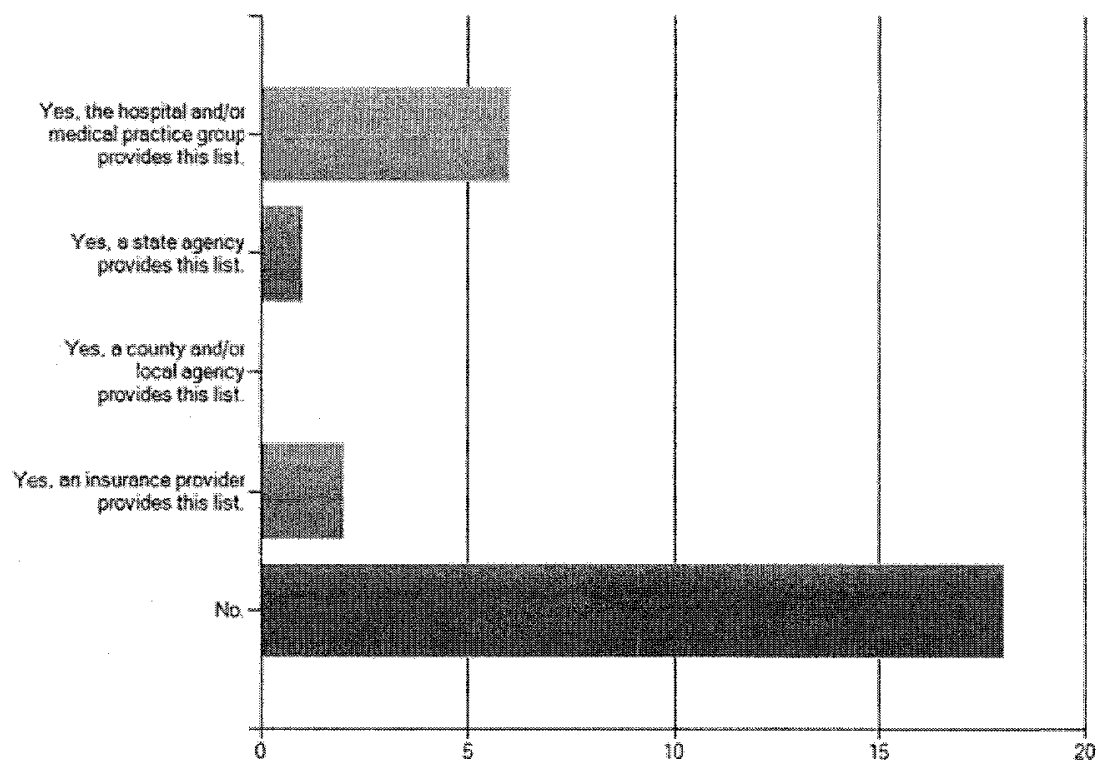

Another recommendation is state oversight of psychotropic medication of children. There is a need for physicians to report certain information to a statemonitoring agency. ${ }^{345}$ Mandated reporting should include:

1. Prescribing psychotropic medications to children under five;

2. Prescribing multiple psychotropic medications within the same drug class;

3. Prescribing medication to minors that exceeds a dosage exceeding FDA limits;

4. Prescribing medication not approved for use in children.

343. Id., at Question 15.

344. Id.

345. See Naylor, supra note 58, at 183-85 (noting that some states provide oversight of psychotropic medications administered to minors in state care by requiring all responsible adults overseeing the child's case to participate in the treatment plans and providing programs dedicated to reviewing the assigning of psychotropic drugs to minors). 
In the following chart, you may choose more than one response. For reasons explained below, I have prescribed psychotropic medication to a child that ...

\begin{tabular}{|c|c|c|c|c|c|c|c|}
\hline & \begin{tabular}{|l|} 
It was \\
the best \\
medication \\
for the \\
symptoms \\
presented.
\end{tabular} & $\begin{array}{l}\text { No other } \\
\text { medications } \\
\text { were } \\
\text { available. }\end{array}$ & $\begin{array}{l}\text { This } \\
\text { practice } \\
\text { represents } \\
\text { the } \\
\text { standard } \\
\text { of care. }\end{array}$ & $\begin{array}{l}\text { The practice is } \\
\text { approved by a } \\
\text { hospital and/or } \\
\text { medical practice } \\
\text { group. }\end{array}$ & $\begin{array}{l}\text { The practice is } \\
\text { approved by a } \\
\text { government } \\
\text { agency. }\end{array}$ & $\begin{array}{l}\text { The practice } \\
\text { is approved } \\
\text { by a } \\
\text { professional } \\
\text { association. }\end{array}$ & $\mathrm{N} / \mathrm{A}$ \\
\hline $\begin{array}{l}\text {...was not } \\
\text { recommend-ed } \\
\text { by the FDA for } \\
\text { use in minors. }\end{array}$ & $56.7 \%$ & $33.3 \%$ & $66.7 \%$ & $16.7 \%$ & $6.7 \%$ & $33.3 \%$ & $33.3 \%$ \\
\hline $\begin{array}{l}\text {...exceeded } \\
\text { dosage } \\
\text { recommendation } \\
\text { s. }\end{array}$ & $48.3 \%$ & $20.7 \%$ & $34.5 \%$ & $6.9 \%$ & $3.4 \%$ & $17.2 \%$ & $48.3 \%$ \\
\hline $\begin{array}{l}\text {...exceeded more } \\
\text { than two } \\
\text { psychotropic } \\
\text { prescriptions for } \\
\text { an individual } \\
\text { child. }\end{array}$ & $46.7 \%$ & $16.7 \%$ & $46.7 \%$ & $13.3 \%$ & $6.7 \%$ & $23.3 \%$ & $50.0 \%$ \\
\hline $\begin{array}{l}\text {...exceeded more } \\
\text { than one } \\
\text { psychotropic } \\
\text { medication in a } \\
\text { particular drug } \\
\text { class. }\end{array}$ & $37.9 \%$ & $17.2 \%$ & $34.5 \%$ & $6.9 \%$ & $3.4 \%$ & $17.2 \%$ & $55.2 \%$ \\
\hline $\begin{array}{l}\text {... was under five } \\
\text { years of age. }\end{array}$ & $46.7 \%$ & $26.7 \%$ & $33.3 \%$ & $10.0 \%$ & $6.7 \%$ & $33.3 \%$ & $50.0 \%$ \\
\hline
\end{tabular}


I you wer examining a minor patient for the trist time, which of the following oxisting conditons would caus you concern? check all that apply.

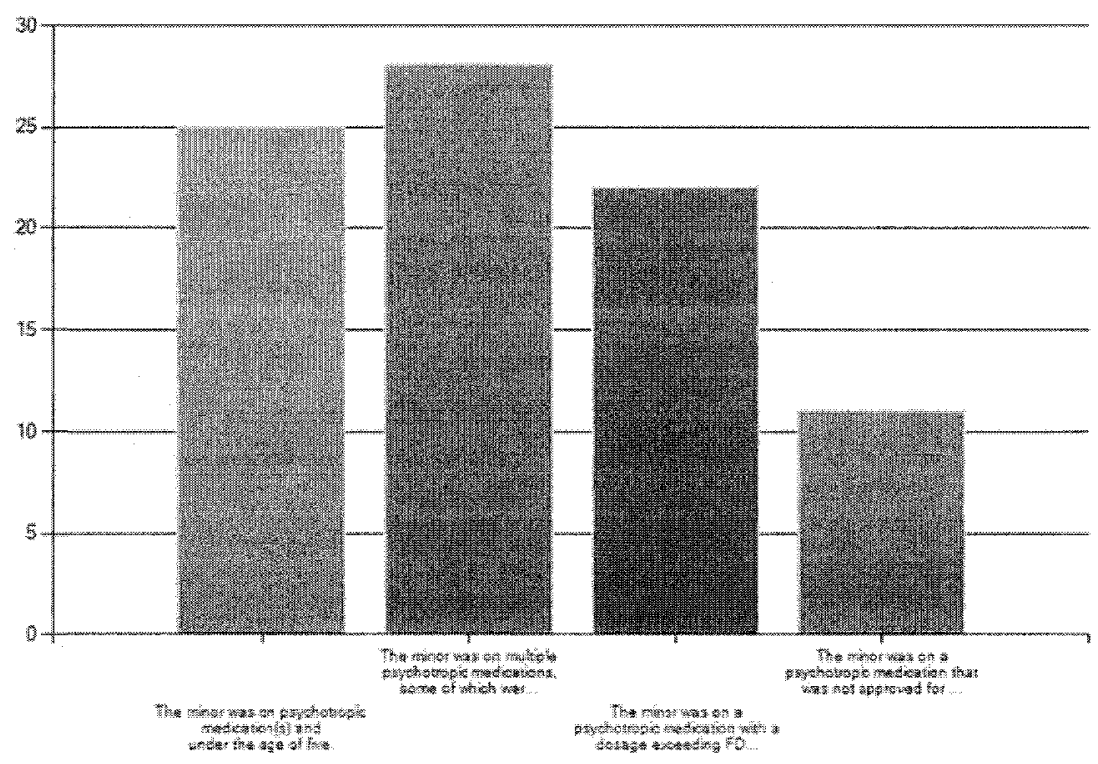

The recommendations above were highlighted in the survey responses as concerns by those responding. ${ }^{346}$ When questions on the survey focused specifically on foster children, the higher rates of medication for foster children is indicated. ${ }^{347}$ Eight respondents had significant concerns, however eight indicated there were reasonable explanations for the procedure.

346. Stone Survey, supra note 325, at Question 18. The top response was minors on multiple medications within the same drug class. See id. at Question 19 (reporting, however, is rarely mandated).

347. Id. at Question 20. 


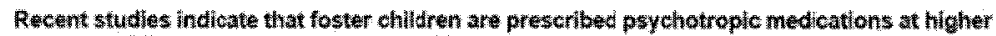

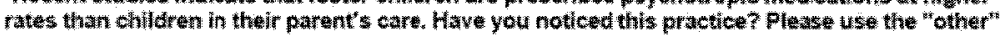
box for further explanation.

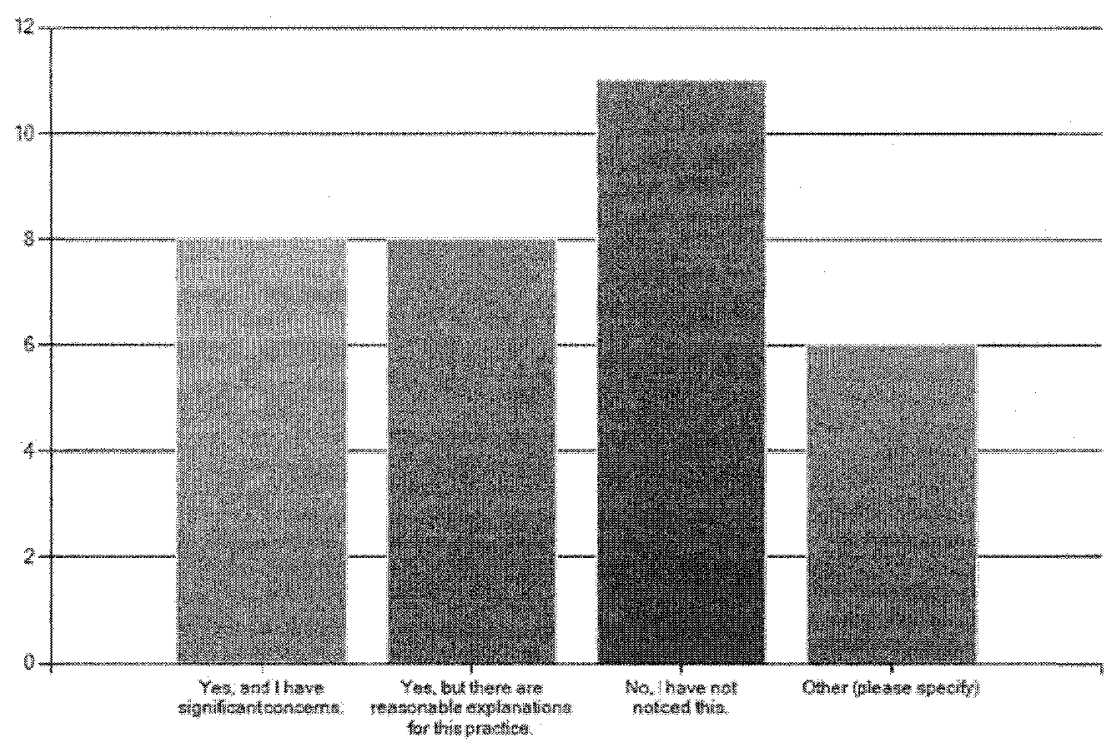

The reasons why children in foster care are medicated at higher rates than nonfoster children complex. The primary reason explained in the survey responses is the lack of stability and frequent moves associated with being in foster care. ${ }^{348}$ Other reasons include more contact with psychiatrists and treatment facilities, referrals by schools because of in school behavior, and more contact with the criminal justice system..$^{349}$ 
If you have noticed higher rates of psychotropic medicstion use in foster chitdren, why, in your opinion, is this happening? Check all that apply.

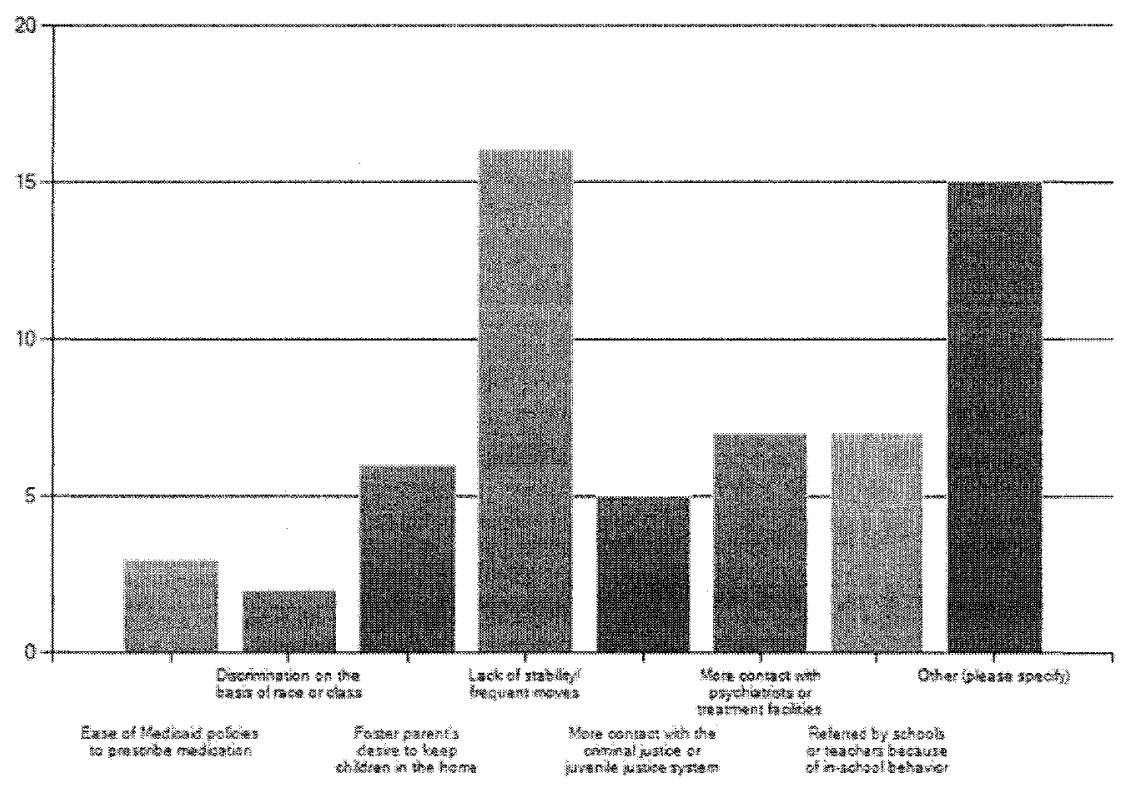

Clearly, the overmedication of foster children is a grave concern that should be addressed by the health care, social service, and legal communities. ${ }^{350}$ Alternatives to psychotropic medication should be explored, and the ease with which parents and social service agencies can override a minor's refusal to consent to psychotropic medication should be restricted and more closely scrutinized.

\section{CONCLUSION}

No doubt, there are competing interests among the psychiatric community, foster care system, and parents in the treatment of mentally ill children. States should acknowledge the authority of mature minors in the right to consent to or refuse psychotropic medication. All parties will benefit from a more informed patient who is prescribed medication to treat a mental illness. Our vulnerable foster care children should be particularly monitored by an independent body to scrutinize the prescribing of psychotropic medication.

A spotlight must be pointed at the mental health system for children to shine light on the process of medicating our mentally ill children. The risks and benefits of psychotropic medication should be reviewed, the consent and refusal authority

350. Id.; see also Naylor, supra note 58, at $186-90$ (noting that changes must be made to the process of consenting to psychotropic medications, child welfare agencies should partner with academics to develop better methods for monitoring psychotropic medications, legislators need to draft laws to better ensure such oversight, and caseworkers and clinicians should work to ensure that there is a better system to research policies about consent and psychotropic medications). 
should be more clearly articulated, and hopefully all children with mental illness, particularly foster children, will benefit. 


\section{Appendix A: Sample Consent Form}

\section{Authorization to Administer Psychotropic Medications \\ Informed Consent Form}

Child's Identifying Information:

Child's Name:

Date of Birth:

Sex:

Height:

Weight:

Prescribing Health Care Provider:

Name:

Facility Name:

Address:

Tel. Number:

Setting:

_. Psychiatric Hospital

RTC

Foster or Group Home

Shelter

Outpatient Facility

Detention Center

Other

Reason for Request:
Continue Current Medication Only
New Medication
Dosage Adjustment
Emergency Use (PRN Order)
Other

If hospitalized, patient is admitted as a:

Voluntary Admission
Involuntary Admission

Clinical Reason for Request:

DSM-5 Diagnosis:

Allergies/Adverse Reactions:

Current Psychotropic Medications:

Medication:

1. Dosage:

2. Administration Schedule:

Medication:

1. Dosage:

2. Administration Schedule: 
Current Non-Psychotropic Medications (including nutritional supplements):

Discontinued Psychotropic Medication:

New Medications: (add additional sheets if more than one new medication is prescribed.)

Name of Medication:

Dosage/Frequency:

Duration of Administration (not to exceed 90 days prior to review and renewal period):

Target Symptoms:Benefits/Intended Outcomes:

Potential Side Effects:

Likely Results of Not Taking Medication:

Tests/Procedures required before/during regimen:

Alternate Treatments (including reasons these treatments were rejected):

FDA Approval:

I agree that I have discussed the following information with my behavioral health medical practitioner for each medication listed below:

- The diagnosis and target symptoms for the medication recommended;

- The possible benefits/intended outcome of treatment, and as applicable, all available procedures involved in the proposed treatment;

- The possible risks and side effects;

- The possible alternatives, and the explanation of why each alternative was not chosen;

- The possible results of not taking the recommended medication;

- The possibility that my medication dose may need to be adjusted over time, in consultation with my psychiatrist, pediatrician, or other physician;

- My right to actively participate in my treatment by discussing medication concerns or questions with my behavioral health medical practitioner;

- If I am a child 16 years old or older, or a parent or guardian of the child; my right to refuse or withdraw voluntary consent for medication at any time;

-Prior to medication being administered involuntarily, the right to request an administrative hearing.

I understand the medication information that has been provided to me. By signing below I agree to the use of each medication.

Child, aged 16 or over

$\overline{\text { Parent/Guardian if child is under age } 16}$ 


\section{Appendix B: Survey}

\section{Please fill in the following demographic information:}

a. Is your primary specialty child psychiatry, adult psychiatry, or pediatrics?

b. What is your job title?

c. In what state do you practice?

d. How many years have you been a physician?

e. Gender?

f. In what type of facility do you practice? (public or private?)

g. In what type of setting do you practice (inpatient, outpatient, or both?)

h. What type of patients do you primarily come in contact with? (mainly children, mainly adults, or both?)

i. Do you treat foster children? (often, occasionally, rarely, never)

$\mathrm{j}$. Approximately how many children have you seen as patients in the past 12 months? (1-10, 11-25, 26-50, 50-100, over 100)

2. In an in-patient setting, when you prescribe a psychotropic medication to a minor in the care of a social service agency, who provides informed consent?

a. Parent or Legal Guardian

b. Social Services Case Worker

c. Social Services Designated Medical Consent Officer

d. Court Official

e. Child (Please provide an age of consent, if utilized, in the comment box below)

f. Other (please specify)

3. In an out-patient setting, when you prescribe a psychotropic medication to a minor in the care of a social service agency, who provides informed consent?

a. Parent or Legal Guardian

b. Social Services Case Worker

c. Social Services Designated Medical Consent Officer

d. Court Official

e. Child (Please provide an age of consent, if utilized, in the comment box below)

f. Other (please specify)

4. How does the informed consent process change if a psychotropic medication is administered on an emergency, and foreseeably temporary, basis? (For example, PRN orders)

a. Consent is not required for emergency situations

b. A lack of consent can be overridden by a physician or other medical professional in emergencies.

c. Informed consent for the initial prescription includes a provision allowing supplemental emergency prescriptions, as needed.

d. The informed consent process does not change for emergency prescriptions.

e. Other (please specify) 
5. Prior to obtaining informed consent, what information do you provide to the party giving consent? Please check all that apply.
a. Adverse reactions
b. Alternative medications or treatments, and associated risks and benefits
c. Benefits/Intended outcome
d. Contraindications
e. Diagnosis and targeted symptoms
f. Dosage
g. Duration
h. Explanation of procedure if consent is not obtained (including consent override, court order, etc.)
i. FDA status of the medication/level of evidence supporting the recommended medication
j. Frequency range
k. Right to withdraw treatment by consenting party
1. Seek consent of child in addition to parent/guardian
$\mathrm{m}$. Warnings or precautions
n. Other

6. Do you utilize a standardized consent form prior to prescribing a psychotropic medication to a minor?
a. Yes (Answer Question 7)
b. No (Answer Question 8)

7. If a standard consent form is utilized, who developed the form?
a. Department of Social Services (City, County, or Local)
b. Department of Social Services (State)
c. Other Government Agency (Explain below)
d. Insurance Provider
e. Professional Association (Explain below)
f. Other (please specify)

8. If a standard consent form is not utilized, do you follow a consent policy?

a. Yes, provided by the medical facility.

b. Yes, provided by a state government agency

c. Yes, provided by a county, city, local, or agency

d. Other (please specify)

9. In an in-patient setting, is there a procedure to override a minor's refusal to take psychotropic medication, similar to procedures established when an adult refuses to take psychotropic medication?

a. Yes, as provided by state law

b. Yes, as provided by hospital policy 
c. No, there is no process in place. As the treating psychiatrist, I am free to make that determination based on the circumstances

d. Other (please specify)

10. In an in-patient setting, who participates in the process governing a minor's refusal to take psychotropic medication? Check all that apply.
a. Attorney
b. Clinical Director
c. Guardian ad litem
d. Minor
e. Other mental health professional
f. Parent or legal guardian
g. Social Services case worker
h. Treating psychiatrist
i. Other (please specify)

11. In an in-patient setting, when a minor refuses to take a psychotropic medication, who makes the final determination to resolve the outcome of that case?

a. Clinical or Medical Director

b. Judge (including Administrative Law Judge, Hearing Officer, etc.)

c. Other (please specify)

12. In an in-patient setting, what steps do you take if a minor refuses to take a prescribed psychotropic medication? Check all that apply.

a. Abide by the minor's refusal to consent and take no further action

b. Facilitate a discussion to encourage the minor to provide consent

c. Obtain the consent of the parent or the minor's case worker to override minor's refusal to consent

d. Obtain the consent of another official to override the minor's refusal to consent (Specify below)

e. Forcibly medicate the minor

f. Seek a court order to medicate the minor

g. Other (please specify)

13. In your opinion, should a minor have the right to refuse the administration of a psychotropic medication? If so, should that right be limited by the age of the minor?

a. Yes, a minor of any age should be able to refuse a psychotropic medication

b. Yes, a minor 10 years of age or over should be able to refuse a psychotropic medication

c. Yes, a minor 12 years of age or over should be able to refuse a psychotropic medication

d. Yes, a minor 14 years of age or over should be able to refuse a psychotropic medication 
e. Yes, a minor 16 years of age or over should be able to refuse a psychotropic medication

f. No, only adults over the age of 18 should be able to refuse a psychotropic medication

14. In your opinion, who should govern the procedure overriding a minor's refusal to consent to psychotropic medications?

a. An independent judicial hearing, run by a government agency or court

b. A hearing within the hospital or treatment center, run by a hospital board or other authorized group

c. Other (please specify)

15. Do you rely on a list of approved psychotropic medications for use in minors? If so, who provides this list? Check all that apply

a. Yes, the hospital and/or medical practice group provides this list

b. Yes, a state agency provides this list

c. Yes, a county and/or local agency provides this list

d. Yes, an insurance provider provides this list

e. No

f. Other (please specify)

16. Do you rely on a list of recommended and/or safe dosage levels or psychotropic medications for use in minors?

a. Yes, the hospital and/or medical practice group provides this list

b. Yes, a state agency provides this list

c. Yes, a county and/or local agency provides this list

d. Yes, an insurance provider provides this list

e. No

f. Other (please specify)

17. For reasons explained below, I have prescribed psychotropic medication to a child that ...

i. ... was not recommended by the FDA for use in minors

ii. ... exceeded dosage recommendations

iii. . . exceeded more than two psychotropic prescriptions for an individual child

iv. ... exceeded more than one psychotropic medication in a particular drug class

v. ... was under five years of age

\section{Answers}

a. It was the best medication for the symptoms presented

b. No other medications were available

c. This practice represents the standard of care

$\mathrm{d}$. The practice is approved by a hospital and/or medical practice group 
e. The practice is approved by a government agency

f. The practice is approved by a professional association

g. N/A

18. If you were examining a minor patient for the first time, which of the following existing conditions would cause you concern? Check all that apply.

a. The minor was on psychotropic medication(s) under the age of five

b. The minor was on multiple psychotropic medications, some of which were within the same drug class

c. The minor was on a psychotropic medication with a dosage exceeding FDA limits

d. The minor was on a psychotropic medication that was not approved for use in children

19. Do you report data pertaining to psychotropic medications to any organization?

a. Yes, to a state social services agency

b. Yes, to a county and/or local social services agency

c. Yes, to the state Medicaid agency

d. Yes, to the hospital board and/or the medical practice group head e. No.

20. Recent studies indicate that foster children are prescribed psychotropic medications at higher rates than children in their parent's care. Have you noticed this practice? Please use the "other" box for further explanation.

a. Yes, and I have significant concerns

b. Yes, but there are reasonable explanations for this practice

c. No, I have not noticed this

d. Other (please specify)

21. If you have noticed higher rates of psychotropic medication use in foster children, why, in your opinion, is this happening? Check all that apply.
a. Ease of Medicaid policies to prescribe medication
b. Discrimination on the basis of race or class
c. Foster parent's desire to keep children in the home
d. Lack of stability/frequent moves
e. More contact with the criminal justice or juvenile justice system
f. More contact with psychiatrists or treatment facilities
g. Referred by schools or teachers because of in-school behavior
h. Other (please specify) 